\title{
ASSOCIATING THE IMAGE WITH THE MYTH ON ANCIENT CRETAN COINS: THREE CASE-STUDIES*
}

\author{
Manolis I. Stefanakis - Niki Paschalia M. Konstantinidi \\ Professor in Classical Archaeology and Numismatics - Classical Philologist, Ph.D., M.ed. \\ Department of Mediterranean Studies \\ University of the Aegean \\ stefanakis@rhodes.aegean.gr - alinaconstantinidi@gmail.com
}

\begin{abstract}
Cretan coinage is characterized by a multitude of iconographic types, very often mythological in content. Various mythical figures and episodes are often difficult to identify or interpret due to either lack of clues that would lead to an interpretation or to the fact that could be identifiable with more than one existing myth. Thus, the identification of imagery on Cretan coins is not always self evident. Three major mints of the island are examined in this paper in order to investigate local myths, compared with the mythological tradition of mainland Greece; the myth of the Tree Nymph of Gortyn, the myth of the Labyrinth of Knossos and the myth of the Dog-nursed Infant of Kydonia. Cretan cities, through coin imagery and by carefully selecting the represented mythical figures, were bonding their citizens with a certain heritage, offering a sense of belonging, continuation and ethnic pride, differentiating themselves from other ethnic groups and city states of the island.
\end{abstract}

KeYwORDS: Ancient coins, Crete, Gortyn, Knossos, Kydonia, cretan myths.

ASOCIANDO LA IMAGEN CON EL MITO EN MONEDAS CRETENSES ANTIGUAS:

TRES CASOS DE ESTUDIO

\section{RESUMEN}

La acuñación de moneda cretense se caracteriza por una multitud de tipos iconográficos, muy a menudo de contenido mitológico. Varias figuras y episodios míticos suelen ser difíciles de identificar o interpretar debido a la falta de indicios que conduzcan a una interpretación o al hecho de que podrían identificarse con más de un mito existente. Por lo tanto, la identificación de la imaginería en las monedas cretenses no siempre es evidente. En este artículo se examinan las tres casas de la moneda principales de la isla para investigar los mitos locales, en comparación con la tradición mitológica de la Grecia continental; el mito de la ninfa del árbol de Gortina, el mito del laberinto de Cnosos y el mito del niño de Cidonia amamantado por una perra. Las ciudades cretenses, a través de la imaginería de las monedas y seleccionando cuidadosamente las figuras míticas representadas, vinculaban a sus ciudadanos con un cierto legado cultural, ofreciendo un sentido de pertenencia, continuación y orgullo étnico, diferenciándose a sí mismas de otros grupos étnicos y ciudades estado de la isla.

Palabras Clave: Monedas antiguas, Creta, Gortina, Cnosos, Cidonia, mitos cretenses. 
Coins in antiquity served various purposes other than their purely transactional use. Their iconography was used for religious, political and national propaganda, reproducing narrative scenes or figures and symbols from the past and the history of each city. ${ }^{1}$ Greeks having no background of a long historical tradition and being trapped between the occult desire for knowledge and the limited boundaries of oral memory, created and used myths to solve the mystery of their origin and past. An amount of these myths were very often imprinted on coins.

In this context, Cretan coinage is also characterized by a multitude of iconographic types, very often mythological in content. ${ }^{2}$ Three major mints of the island (fig. 1) are examined below in order to investigate local myths, compared with the mythological tradition of mainland Greece; namely the myth of the Tree Nymph of Gortyn, the myth of the Labyrinth of Knossos and the myth of the Dog-nursed Infant of Kydonia.

\section{A NYMPH CALLED EUROPA}

One of the most famous myths of Crete during antiquity was the myth of Europa. Legend has it that Zeus fell in love with Phoenix's daughter, transformed himself into a gentle white bull, approached her and laid down at her feet. When, full of admiration, Europa climbed on his back, the animal stood up suddenly and jumped into the sea, bringing the nymph to the Diktean Cave or to Gortyn, where the sacred wedding followed. ${ }^{3}$

The arrival of Europa in Crete sitting on the back of the bull is unquestionably represented on the obverse of the earliest silver Cretan -and presumably alliance coinages- of Gortyn ${ }^{4}$ and Phaistos ${ }^{5}$ (figs 2-3) in the second quarter of the $5^{\text {th }} \mathrm{c}$. BC, ${ }^{6}$ and again on the silver issues of both cities of the early $4^{\text {th }} \mathrm{c}$. BC (figs 4-5).

* Many thanks are owed to dear friends and colleagues Dr. Nikos Litinas and Dr. Federico Carbone, for discussing issues of this paper and offering useful insights into various matters and Mrs Anna Kouloumbri for saving the manuscript from many language incorrections.

${ }^{1}$ On coinage and propaganda in general see $\Lambda \dot{\alpha} \alpha \mu \pi \eta, 2017$. On roman coinage and propaganda see indicatively Alföldi, 1956.

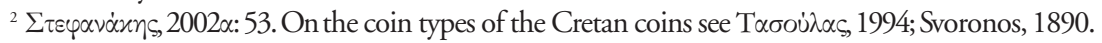

${ }^{3}$ On the myth of Europa see Andrews, 1969; Bühler, 1968; Reeves, 2003.

${ }^{4}$ On the mint of Gortyn, see Carbone, 2014-2015: 70-83, 91-113; $\sum \tau \varepsilon \varphi \alpha \nu \alpha x \eta, ~ 2019 \alpha$; Jackson, 1971a; Le Rider, 1966: 129-172 (sporadically); Svoronos, 1890: 153-182.

${ }^{5}$ On the mint of Phaestos see Carbone, 2014-2015: 84-90, 114-123; $\Sigma \tau \varepsilon \varphi \alpha \nu \dot{\alpha} x \eta, 2019 \beta$; Le Rider, 1966: 129-172 (sporadically); Svoronos, 1890: 253-265.

${ }^{6}$ Carbone, 2014-2015: 70, 91, 109, 120 (470-425 BC); Le Rider, 1966: 194 (450/425-360?

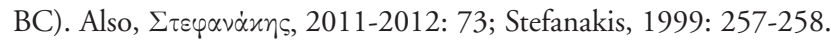

${ }^{7}$ Carbone, 2014-2015, 109 (425-350 BC); Le Rider, 1966. 194 (450/425-360? BC); Also,

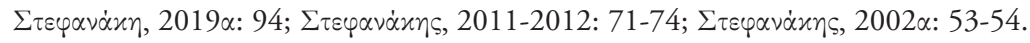


The type, common in the $6^{\text {th }}$ and $5^{\text {th }} \mathrm{c}$. BC vase painting, ${ }^{8}$ reflects the depiction on the archaic metope from Temple $\Upsilon$ of Selinus (c. 550-540 BC)..$^{9}$ Graceful also is a relevant representation on the staters of a short issue of Phaistos, where the bull accosts the seated nymph, who caresses him (fig. 6)..$^{10}$

Around the middle of the 4th c. BC, Gortyn issued a new series of silver staters ${ }^{11}$ with new types, depicting on the obverse a female figure sitting pensively (turned half right or left) within the branches of a tree (fig. 7), while a bull (standing right or left) is depicted on the reverse. ${ }^{12}$ The specific type was copied by the neighboring mint of Sybritos (fig. 8), for a short time. ${ }^{13}$ The figure has been identified with Europa, Britomartis, Ellotis, Velchane or just an anonymous nymph of the trees, ${ }^{14}$ with the identifications with Britomartis and Europa being the most persistent, for both myths contain elements that connect each nymph to a tree.

The identification with Britomartis has been argued by Svoronos ${ }^{15}$ and in the context of the Hymn to Artemis, which was composed by Callimachus, in the first half of the $3^{\text {rd }}$ c. BC:

...And beyond others thou lovest the nymph of Gortyn, Britomartis, slayer of stags, the goodly archer; for love of whom was Minos of old distraught and roamed the hills of Crete... ${ }^{16}$

On the other hand, Theophrastus in the second half of the $4^{\text {th }} \mathrm{c} . \mathrm{BC}$, narrates:

...It is said that in Crete, in the district of Gortyn, there is a platanus (plane tree) near a certain spring, which does not lose its leaves; (indeed the story is that it was under this tree that Zeus lay with Europa)... ${ }^{17}$

So, who could be the nymph depicted on the Gortynian coins? Both of the lovers mentioned in the ancient sources (Minos and Zeus), have as their symbol the bull depicted on the reverse of the coin, a coincidence that does not facilitate

${ }^{8}$ See LIMC IV, Europa I, 24-59. On the depictions of Europa and the bull in ancient Greek art

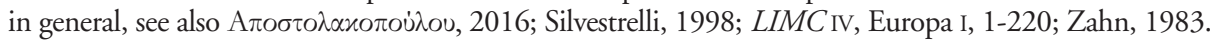

${ }^{9}$ On the metope see indicatively, Marconi, 2007: 90-96; Østby, 1987; Kähler, 1949: 37-38.38.

${ }^{10}$ Carbone, 2014-2015: 120 (425-320 BC); Le Rider, 1966: (450/25-360?), pl. xx, 25; Svoronos, 1890: pl. XXII, 35-37; cf. Moschus, Europa, 89-99.

${ }^{11}$ Carbone, 2014-2015: 110-111 (350-260 BC); Le Rider, 1966: 194 (360/50-280/70 BC).

${ }^{12}$ See also Svoronos, 1894a: 3.

${ }^{13} \sum \tau \varepsilon \varphi \alpha \nu \dot{\alpha} x \eta \varsigma, 2019 \beta$ : 74; Carbone, 2014-2015: 445-447; $\sum \tau \varepsilon \varphi \alpha \nu \dot{\alpha} \varkappa \eta \varsigma$, 2011-2012: 74-76; $\sum \tau \varepsilon \varphi \alpha v \dot{\alpha} x \eta \varsigma, 2002 \alpha$ : 54. On the mint of Sybritos in general, $\Sigma \tau \varepsilon \varphi \alpha \nu \dot{\alpha} x \eta \varsigma, 2019 \beta: 74-76 b ; \sum \tau \varepsilon \varphi \alpha \nu \dot{\alpha} x \eta \varsigma$, 2011-2012: 74-76; Guarducci, 1949; Naster, 1947; Svoronos, 1890: 313-317, pls XXX, 12-XXXI, 13.

${ }^{14} \sum \tau \varepsilon \varphi \alpha \nu \dot{\alpha} x \eta \varsigma$, 2011-2012; Stefanakis, 2000a: 84-85.

${ }^{15}$ Svoronos, $1894 \mathrm{a}-\mathrm{b}$.

${ }^{16}$ Callimachus, Hymns and Epigrams. Hymn to Artemis, 189-192.

${ }^{17}$ Theophrastus, Historia Plantarum 1, 9, 5.7-10. 
the interpretation of the obverse type. However, a careful analysis of the iconography of the coins leads to a rather safe conclusion: The nymph appears in more than one narrative scene on the obverse of different stater issues.

The earliest coins of the series, dated around 360-330 BC, ${ }^{18}$ depict on the obverse the nymph sitting pensively within the branches of a tree (fig. 7), while in another issue of possibly slightly later date-span (360/50-322 BC), ${ }^{19}$ the nymph releases her concentration, looks down to the ground and extends her left arm to the right, most likely in a gesture of invitation (fig. 9).

It comes as a consequence of that gesture that, in the coins dated between 322 and $300 \mathrm{BC}^{20}$ the trunk of the tree is transformed into the head of an eagle (fig. 10), while on another issue of the same period an eagle sits on a branch to the left, next to the nymph (fig. 11). In the next three series, all dated between 300 and $270 \mathrm{BC},{ }^{21}$ the nymph is presented as a legal spouse, lifting her veil with the left hand and looking towards the eagle standing left on the left (fig. 12). Next, the eagle, with its wings wide open, couples with the half nude nymph, who keeps her veil up with the right hand and holds the eagle, with her left, in her lap (fig. 13). This last representation seems to copy -or at least is likely to be influenced by- the well-known statue complex of Leda and the Swan, the work of the sculptor Timotheus from Epidaurus, of the early $4^{\text {th }}$ c. BC..$^{22}$

Finally, in the third issue of the period, as a sign that the Holy Wedding has taken place, the nymph is represented as a legitimate wife of Zeus, bearing the symbols of Hera, that is, wearing a polos cup on her head and holding a cuckoo-tipped scepter (fig. 14) ${ }^{23}$ The legitimate spouse revealing herself to the eagle is again represented on the one and short-lived issue (fig. 15) of the next period, 260-250 BC, ${ }^{24}$ characterized by a debasement of coinage in the major mints. ${ }^{25}$

The fact that the courting process and the completion of a sacred wedding are depicted indicates that the bride on the tree is Europa, with whom Zeus was united (the eagle-lover is the symbol and transformation of Zeus), to give birth to Minos.

${ }^{18}$ Le Rider, 1966. 194. Carbone (2014-2015) has not attempted any specific dating for the various individual issues of the series, generally dating all of them to the years 350-260 BC.

${ }^{19}$ Le Rider, 1966: 194.

${ }^{20}$ Le Rider, 1966: 194.

${ }^{21}$ Le Rider, 1966: 194.

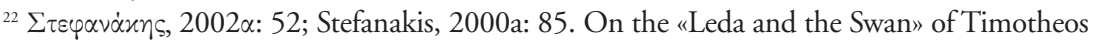
see indicatively, Rieche, 2010; LIMC VI, 5-7, 73; Rieche, 1978.

${ }^{23} \sum \tau \varepsilon \varphi \alpha v \dot{\alpha} \varkappa \eta \varsigma, 2011-2012$ : 78; $\sum \tau \varepsilon \varphi \alpha v \dot{\alpha} x \eta \varsigma, 2002 \alpha$ : 52-53; Stefanakis, 2000a: 85. Comp.

LIMC IV, Hera 154 and 168 for similar depictions on pottery.

${ }^{24}$ Carbone, 2014-2015: 111 (260-250 BC). The issue was wrongly dated by $\sum \tau \varepsilon \varphi \alpha \nu \alpha \dot{\alpha} \eta \bar{s}$ $(2011-2012,77)$ to the years 300-280/70 BC and thus identified as an issue of the earlier series.

${ }^{25}$ On the shortage of silver in the east Mediterranean in the early $3^{\text {rd }} \mathrm{c}$. BC see $\sum \tau \varepsilon \varphi \alpha \nu \dot{\alpha} \alpha \eta \varsigma_{s}$, 2011-2012: 79-82; Stefanakis, 2000b: 201. 
Therefore the nymph is transformed finally to the bride of Zeus and the queen of Crete, equal to Hera. The step by step registering of the different myth's phases describes in detail an event of which the final chapter is briefly described by Theophrastus: «it was under this tree that Zeus lay with Europa». ${ }^{26}$ Consequently, in these Gortynian coins we have the depiction of a mythical episode, which clearly testifies to the identity of the nymph, offering more visual details of the story. ${ }^{27}$

Britomartis is, on the other hand, known from the mythographers that she chose to throw herself, into the sea rather than being violated by Minos. Therefore

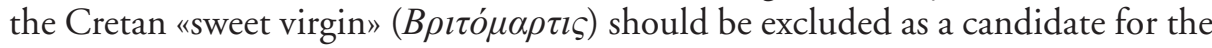
identification with the represented figure.

The earlier representation of Europa, riding a galloping bull, re-appeared eventually on the new coinage of Gortyn around after the middle of the $3^{\text {rd }} \mathrm{c} . \mathrm{BC}$. This time the mantel of the nymph is filled with the wind over her head floating as it were a sail, ${ }^{28}$ on the reverse of the new silver drachms of the city (fig. 16). In some cases, on the large bronze fractions of the same period, the seated spouse of the eagle on the tree (obverse), is clearly associated with Europa seated on the back of the bull (reverse) (fig. 17)..$^{29}$ The type is also combined with a square maze on the reverse (fig. 24) on a short bronze issue, possibly a product of a short alliance with Knossos in the last quarter of the $3^{\text {rd }} \mathrm{c}$. BC..$^{30}$ The new type of Europa and the bull may be plausibly copying some sculptural group dedicated in the town, such as the late Hellenistic (ca $100 \mathrm{BC}$ ) and partially surviving marble group of Europa seated on back of bull with two dolphins forming support at front, a work of natural size, discovered in the great theater of Gortyn and currently in the care of the British Museum. ${ }^{31}$

Europa was indeed the major figure on the coinage of Gortyn for many centuries as a strong symbol of autochthony. The numismatic iconography of Europa evolved through the years and it is very interesting to observe a possible attempt of the mint to depict a sequence of scenes on a number of consecutive silver stater issues from circa the mid $4^{\text {th }} \mathrm{c}$. BC to circa $270 \mathrm{BC}$ (figs 7-14). Of course Europa should not be the only image that should be carefully analyzed. As Carbone correctly pointed out ${ }^{32}$ the tree is also an issue that should be considered within this sequence of iconographic development, since sometimes it is depicted bare, in some cases it bears

${ }^{26}$ Theophrastus, Historia Plantarum 1.9.5,9-10.

${ }^{27} \sum \tau \varepsilon \varphi \alpha \nu \dot{\alpha} x \eta$ s, 2011-2012: 83; Stefanakis, 2000a: 85.

${ }^{28}$ In accordance with the description of Moschus, Europa, 129-130: «the robe went bosoming deep at the shoulder like the sail of a ship".

${ }^{29}$ Svoronos, 1890: pl. XV, 20-28.

${ }^{30}$ Carbone, 2014-2015: 111 (250-200 BC); Jackson, 1971b: 291-292.

${ }^{31}$ The British Museum inv. no 1862,0201.01 <https://www.britishmuseum.org/collection/

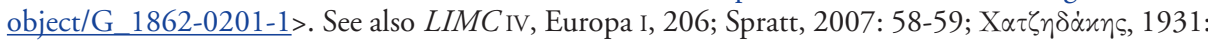
9-10; Waldhauer, 1915: 63-68.

${ }^{32}$ Dr. Federico Carbone, pers. com. 
buds only and in others cases it is in full blossom, let alone the bull on the reverse, who is depicted in different stances and actions. ${ }^{33}$

In any case, if these different issues are indeed correctly dated, then one may discern a carefully selected and executed iconographic program, perhaps the first and only known iconographic coinage program in the ancient world. ${ }^{34}$ Apparently a political decision of the authorities of Gortyn to «shed light» on more personal moments of Europa, in order to further proclaim to their citizens and the outer world the monopoly of -and their ties to- the mother of all Cretans and legitimate spouse of Zeus.

\section{THE MAZE OF KNOSSOS: THE LABYRINTH OR NOT THE LABYRINTH?}

The legend of the Labyrinth and its monstrous inhabitant, the Minotaur comes as a sequence to the myth of Europa and was fully developed in the Hellenistic and Roman times. ${ }^{35}$ When Minos, out of wonder or greed, decided not to sacrifice the sensational Bull sent to him by Poseidon and instead offered the god another inferior animal, Poseidon became angry and implanted in Minos' wife, Queen Pasiphae, ardent desire for the bull. The Queen managed to couple with the bull and from their union a monster with a human body and a bull's head was born, named Minotaur, ${ }^{36}$ whom Minos imprisoned in the Labyrinth. The Labyrinth, a work of Daedalus, was a strange edifice with many corridors and complicated turns, with an easily accessible entrance but an almost impossible exit. ${ }^{37}$ The unspecified cause of death of Androgeos, son of Minos, during the athletic contests organized by the king of Athens, Aegeas, provoked the wrath of Minos who, consequently, mobilized his fleet, conquered Megara and besieged Athens. Nevertheless, Minos would have never conquered Athens, if it was not be for his father, Zeus, sending a plague, which forced the Athenians to resort to the oracle of Delphi. ${ }^{38}$ The oracle ordered the Athenians to pay compensation for Androgeo's murder and to allow Minos determine the retribution. What followed was annual blood tax of seven young men and seven young women, as pray for the Minotaur. ${ }^{39}$ Theseus' decision to cease this monstrous tax ${ }^{40}$ led to the extinction of the Minotaur in the Labyrinth with the help of Ariadne. ${ }^{41}$

\footnotetext{
${ }^{33}$ On various examples see Carbone, 2014-2015: cat. nos 59-102; Le Rider, 1966: pls. XI-XIX.

${ }^{34}$ On the iconographic program see also $\sum \tau \varepsilon \varphi \alpha \nu \alpha x \eta n s, ~ 2011-2012:$ 76-79; Stefanakis, 2000a: 85.

${ }^{35}$ Litinas 2011, 466-467.

${ }^{36}$ Ovidius, Metamorphoses 8.81.

${ }^{37}$ Apollodorus, Library Epitome, 3.1.

${ }^{38}$ Pausanias, Description of Greece, Attica, 1.27.10.

${ }^{39}$ Plato, Minos, 321a.

${ }^{40}$ Isocrates, Encomium of Helen, 10.27.

${ }^{41}$ Apollodorus, Library Epitome, E.1.
} 
The mythical past of Knossos, primarily connected with the figures of Minos, the Minotaur, Ariadne and the maze holds a leading position in the monetary iconography of Knossos from the late $5^{\text {th }} \mathrm{c}$. BC onwards. ${ }^{42}$ Three major mythological figures are depicted on the obverse of the earlier silver series of Knossos, with a labyrinthine motive or a maze being the most common feature on the reverse: the Minotaur running in an «archaic» manner left or right with head facing (fig. 18a-b), is one of the most basic and earliest monetary types of the Knossian mint, dated from 425(?) to 360(?) BC.43 The decorated head of Ariadne appears in the same period on the reverse of a silver stater issue (fig. 18c), as well as on the silver series of the periods 360/50-320(?) ${ }^{44}$ (fig. 19a-c) and 320-300 BC 45 (fig. 20); On the obverse of the staters of the period 360/50-320(? ${ }^{46}$ King Minos, seated left on his throne, holding a scepter on the left hand and a phiale on the right, is combined with Ariadne on the reverse (figs 19b-c). On later drachm issues, of 300-280/70 BC $\mathrm{B}^{47}$ the throne is replaced by a square maze and the king holds the scepter in his left hand and a small Victory on his right palm (fig. 21), an imagery, most likely influenced by the Olympian Zeus of Phidias, ${ }^{48}$ and the reverse type of the silver tetradrachms of Alexander III. ${ }^{49}$

From the inauguration of the Knossian mint, a labyrinthine motive took its place as the «national» symbol of the city, placed mainly on the reverse, but sometimes also on the obverse of the coins. Constantly evolving for the next five centuries, the motive remained a symbol of self-sufficiency, religious power, and economic stability of the city. It was as if a coin was a living organism, the type never ceased to mutate, taking various forms: ${ }^{50}$

As early as circa 425(?) BC and until circa $300 \mathrm{BC}$ the labyrinthine motive appears as a clockwise or counter clockwise hooked cross (swastika) (figs 18a, 20), the antennae of which end up in meanders, with its center often adorned with a floral pattern or a star. Sometimes, it is transcribed into a meandering pattern, which symbolically encloses the head of Ariadne ("the lady of the labyrinth" of the linear B Knossos's tablets?) $)^{51}$ (figs 18c, 19c), the head of the Minotaur (fig. 19a), or the master and owner

${ }^{42}$ On the coinage of Knossos see $\sum \tau \varepsilon \varphi \alpha \nu \dot{\alpha} x \eta$, 2019: 98-99; Devoto, 2019; Jackson, 1968; Le Rider, 1966: 175-180; Svoronos, 1890: 59-95.

${ }^{43}$ Devoto, 2019: 151-152; Le Rider, 1966: 195.

${ }^{44}$ Le Rider, 1966: 195.

${ }^{45}$ Le Rider, 1966: 195.

${ }^{46}$ Le Rider, 1966: 195.

${ }^{47}$ Le Rider, 1966: 195.

${ }^{48}$ On a description of the lost masterpiece see Pausanias, Description of Greece, Elis I, 5.11.1. See also McWilliam - Puttock - Stevenson, 2011; Richter, 1966.

${ }^{49}$ On the imagery of Zeus see Price 1991, vol. I, 27-28.

${ }^{50}$ For discussions on the coin types of Knossos, with particular reference to the labyrinthine

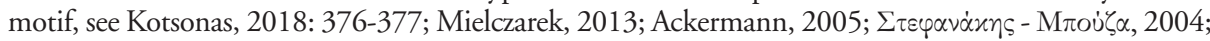
Clayton, 1988; Vin, 1974-1975; Forrer, 1900.

${ }^{51}$ On the doubts expressed on this transcription and interpretation, however, see Litinas, 2011: 459 and n. 17. Also Kotsonas, 2018: 370 and n. 28. 
of the Labyrinth, King Minos himself (fig. 19b). In the period 300-280/70 BC the shape of the swastika is replaced by the square maze, decorated with various complementary symbols: star, arrow, quiver, bull's head, crescent or thunderbolt, while inscriptions also appear. New figures are now associated with it on the obverse of the series: the head of Demeter or Kore, crowned with corn-ears (fig. 22) ) $^{2}$ and the head of Hera (fig. 23), wearing sphendone decorated with palmettes, earring and necklace. ${ }^{53}$

The square maze monopolized the coins for a couple of centuries -until the ceasing of the Knossian mint in $67 \mathrm{BC}$ - and even decorates the reverse of an allied bronze issue of Gortyn and Knossos, of ca 220 BC (fig. 24) with the already mentioned Gortynian type of Europa riding a bull on the reverse. ${ }^{54}$ Towards the end of the $2^{\text {nd }} \mathrm{c}$. BC, the head of Zeus or Minos is associated with the square maze on the local style tetradrachms (fig. 25) and drachms, ${ }^{55}$ while at the same time a circular maze appeared on the reverse of a rather short local style tetradrachm issue depicting the head of Apollo on the obverse $e^{56}$ (fig. 26). Finally, the square maze is placed as a symbol next to the Athenian owl on a Knossian pseudo-Athenian tetradrachm issued at the beginning of the 1st c. BC $\mathrm{B}^{57}$ (fig. 27).

Regarding the depiction of labyrinthine motives and mazes on the Knossian coins two major remarks can be made:

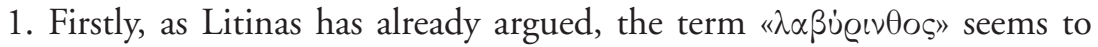
enter and relate to the Cretan mythology, sometime between the end of the $5^{\text {th }}$ and the early $3^{\text {rd }} \mathrm{c} . \mathrm{BC}^{58}$, possibly -and initially- by Euripides and certainly by Callimachus, the earliest known direct source for such a mention..$^{59}$ It could not be surprising that the "labyrinthine» iconography enters the Knossian coin-art by the end of the $5^{\text {th }} \mathrm{c}$. BC (after ca $425 \mathrm{BC}$ ?), in accordance with the contemporary literary sources. It would be ambitious, however, to suggest that the Knossians were using the term « $\lambda \alpha \beta \dot{\jmath} \varrho \iota v \theta o \theta^{\prime}$ " with its later meaning to describe the motives on their coins in the $5^{\text {th }}$ and $4^{\text {th }}$ c. BC, i.e. the swastika type reverse often filled in with meander patterns (figs 18-20), unless - rather unlikely- they were already aware of Euripides work.

Even if the motive has to be related with the mythical Labyrinth, it would only find support more than a century later in inscriptions from the temple of Apollo at Didyma (c. $300 \mathrm{BC}$ ), where the term $\lambda \alpha \beta \dot{\rho} \varrho \iota v \theta$ o denoted dark corridors with floors decorated with meanders in swastika forms.$^{60} \mathrm{It}$ is likely that the later coin

\footnotetext{
${ }^{52}$ On the cult of Demeter and Kore in Knossos see Prent, 2005: 262-263; Coldstream, 1973.

${ }_{53}$ On the series with the head of Hera, see $\sum \tau \varepsilon \varphi \alpha \nu \dot{\alpha} x \eta s, 2017$ : 223-224; Carrier, 2013.

${ }^{54}$ On the alliance coinage of Cnosos and Gortyn see above n. 30.

${ }^{55}$ Le Rider, 1966: 271-285, pl. XXXV1, 1-12; 286-295, pl. XLII, 1.

${ }^{56}$ See, for example, SNG Lockett, 2542; Svoronos, 1890: pl. vI, 18.

${ }^{57}$ Le Rider, 1968: 318, pl. II, 10-12.

${ }^{58}$ Litinas, 2011: 467.

${ }^{59}$ Litinas, 2011: 462-465.

${ }^{60}$ Litinas, 2011: 456 and n. 2.
} 
issues of the period 300-280/70 BC are those that reflect a more consolidated view

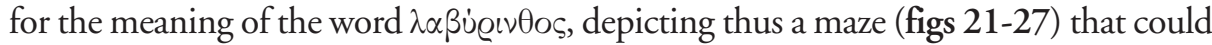
be inspired by the contemporary story of Callimachus, ${ }^{61}$ and which could possibly be called «the Labyrinth». One could also, of course, suggest the opposite, i.e. that Callimachus was inspired by the already existing symbol of the maze on the coins of Knossos...

In any case, the Knossian iconography reflects a mythology which does not seem to make any reference to the famous fight and death of the Minotaur by Theseus. Although the episode is a very popular theme among the attic vase-painters from the $6^{\text {th }} \mathrm{c} . \mathrm{BC}{ }^{, 2}$ the myth is silenced or rather partly ignored by the Cretans at least until the $4^{\text {th }} \mathrm{c}$. BC, providing evidence that the legend of Theseus was a creation of Attica. ${ }^{63} \mathrm{It}$ is possible that the attic myth reflects the fall of the city of Athens under the control of the Cretans, a fact that, disguised as a myth, may allude the era of the Minoan Thalassocracy. Possibly the conditions that the Minoans imposed on the surrendered Mycenaeans of Attica were allegorically described as a blood tax, while the tax collector, the Cretans, were presented as a bloodthirsty monster, the Minotaur. The death of the Minotaur may recall the end of the Minoan power and the establishment of the Mycenaean rule on Crete.

Even in the later, Hellenistic and Roman, periods, when literary sources use Labyrinth as a standard term related to the residence of the Minotaur and the place of the fight, ${ }^{64}$ the Knossian coin iconography never depicted the fight. It is only on a couple of much later Roman issues of bronze drachms of Athens of the $2^{\text {nd }} \mathrm{c}$. $\mathrm{AD}$, with a helmeted head of Athena on the obverse, that the scene of the infamous fight is depicted on the reverse, where Theseus is preparing to slay the monster. ${ }^{65}$

2. Secondly, in relation to the persisting presence, as well as to the variation in the form of the labyrinthine motive, its identification with a specific labyrinthine

${ }^{61}$ Callimachus, Hymns and Epigrams, Hymn to Delos, 308-313: «Then, too, is the holy image laden with garlands, the famous image of ancient Cypris whom of old Theseus with the youths established when he was sailing back from Crete. Having escaped the cruel bellowing and the wild son of Pasiphaë and the coiled habitation of the crooked labyrinth, about thine altar, O lady, they raised the music of the lute and danced the round dance, and Theseus led the choir».

${ }^{62}$ Litinas, 2011: 459, and n. 21. See also LIMC VI, Minos I, 35; Minotauros 6-22.

${ }^{63}$ Litinas, 2011: 465-466.

${ }^{64}$ Litinas, 2011: 466.

${ }^{65}$ See for example, Kroll-Walker, 1993: 189a, pl. 17; 275a-276a, pl. 19; Svoronos, 1975: pl. 98, 1-2; SNG Copenhagen 341; BMC Attica, 762-763, p. XVIII, 9; 764-765, pl. XVIII, 10. The same theme appears on the reverse of the large bronze denominations bearing the bust of Severus Alexander on the obverse, minted ca AD 222-235 at the distant Nicomedia, Bithynia (Voegtli, 1977: 94; SNG von Aulock 784). 
site, «The Labyrinth of Minos», has been a major quest since antiquity and diverse sites have been suggested in the wider area of Knossos and Gortyn. ${ }^{66}$

A) The location of the labyrinth somewhere near Knossos is summarized in the early $3 \mathrm{rd}$ c. $\mathrm{AD}$ in the text of Philostratus:

.... and he [Appolonius] bent his course for Cydonia, and sailed past that place to Knossus, where a labyrinth is shown, which, I believe, once on a time, contained the Minotaur. As his companions were anxious to see this he allowed them to do so, but refused himself to be a spectator of the injustice of Minos, and continued his course to Gortyna because he longed to visit Ida... ${ }^{67}$

Concerning the area of Knossos the quest tends to relate the motive with the Minoan and Mycenaean tradition of the city, identifying the Labyrinth with the Palace of Minos. This identification is based on the location of the palace (Knossos), the complexity and size of its construction, the indications about the conduct of the ritualistic bull-games ( shaped labyrinth on one of the palace's frescoes. The proposed connections of the word «labyrinth" with a term on the Linear B tablets form Knossos ${ }^{68}$ or the Lydian

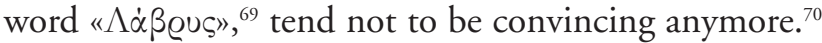

Other scholars, considering that the labyrinth was nothing more than a dance floor or an "orchestra» where Minotaur, Prince of Knossos, performed a ritual dance, have suggested an identification of the labyrinth with the theater based on the NW corner of the palace. Finally, according to other theories the labyrinth was a reflection either of a dance called «Geranos» danced by Theseus and the rescued young people, ${ }^{71}$

${ }^{66}$ On the numerous discussions on the location of the cretan Labyrinth from the $20^{\text {th }}$ century to present, see (indicatively and not exhaustively): Mielczarek, 2013; Paragamian - Vasilakis,

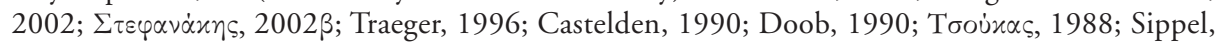
1986; Kraft, 1985; Kern, 1982; Godart, 1975; Shavernoch, 1975; Faure, 1964; $\Lambda \varepsilon \varkappa \alpha \tau \sigma \dot{\alpha} \varsigma, 1964$;

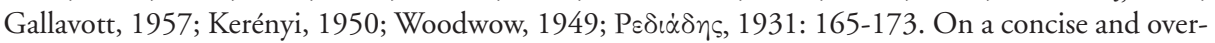
all discussion, tracing the relocation of the Labyrinth from Knossos to Gortyn and back from the Medieval period to modern era, see Kotsonas, 2018.

${ }^{67}$ Philostratus, Life of Apollonius of Tyane, 4.34, 16-22.

${ }^{68} \mathrm{KN} \mathrm{Gg}[1]$ 702.02; KN Oa 745.02; KN Xd 140.01.

${ }^{69}$ Mielczareck, 2013: 127, n. 1 (with further bibliography), 130-132.

${ }^{70}$ See above, n. 51.

${ }^{71}$ «... On his voyage from Crete, Theseus put in at Delos, and having sacrificed to the god and dedicated in his temple the image of Aphrodite which he had received from Ariadne, he danced with his youths a dance which they say is still performed by the Delians, being an imitation of the circling passages in the Labyrinth, and consisting of certain rhythmic involutions and evolutions. This kind of dance, as Dicaearchus tells us, is called by the Delians The Crane, and Theseus danced it round the altar called Keraton, which is constructed of horns ("kerata") taken entirely from the left side of the head...». Plutarchus, Theseus 21.1-2. See also Detienne, 1983. 
or of the mythical games called "Troiae Lusus», organized by Aeneas in memory of his father Anchises, still performed in Italy until Late Antiquity, inspired by the Cretan Labyrinth. ${ }^{72}$

An attempt has been also made to identify the Labyrinth with caves near Knossos. The cave of Hagia Irene was suggested by Chatzidakis in the late $19^{\text {th }} \mathrm{c}$. and Speliara, shortly after by Kalokairinos. ${ }^{73}$ Faure suggested that the Labyrinth may be located at Gouves some $21 \mathrm{~km}$ east of Knossos, currently known as the cave of Agia Paraskevi in the region of Skoteino, a four levels «labyrinthine» cave with a total penetration of 126 meters. In addition to its complexity, the abundance of LMIII period remains are abundant inside the cave, indicate worship during which animal sacrifices were made. ${ }^{74}$ To the above, the cave at Amnissos was lately added as one more likely candidate. ${ }^{75}$

B) From the end of the 4 th and the beginning of the $5^{\text {th }} \mathrm{c}$. AD, however, ancient sources seem to seek the Labyrinth at the area of Gortyn. A first such reference is found in Claudius Claudianus, ${ }^{76}$ while characteristic of this new approach during the $6^{\text {th }} \mathrm{c}$. $\mathrm{AD}$, is the text of Ioannis Malalas:

...so Theseus went immediately to Crete to attack him (Minotaur), while all the senators and the army abandoned Minotaur and decided to flee to the city of Gortyn. When Minotaur learnt about the treachery he also fled to the region of Labyrinth. After he climbed a mountain, he entered a cave to hide. But while he was hunting Minotaur, Theseus heard from someone where he had been hiding. And after he arrived in Gortyn he triumphed against Minotaur...77

With respect to the area of Gortyn, the cave at Ampelouzos, between the villages of Roufas and Plouti, called «the Labyrinth» (fem.), explored and mapped by the Hellenic Speleological Society ${ }^{78}$ has been considered by many to be the mythical

${ }^{72}$ «...As once in Crete, the lofty mountain-isle, that-fabled labyrinthine gallery wound on through lightless walls, with thousand paths which baffled every clue, and led astray in unreturning mazes dark and blind: so did the sons of Troy their courses weave in mimic flights and battles fought for play, like dolphins tumbling in the liquid waves, along the Afric or Carpathian seas...», Virgil, Aeneid 5.580595. This theory gained special attention after the discovery of an Etruscan oinochoe dated as early as the $7^{\text {th }} \mathrm{c}$. $\mathrm{BC}$, which bore the depiction of a round maze, similar to that on the late $2^{\text {nd }} \mathrm{c}$. BC tetradrachms of Knossos (fig. 26), from which horsemen appear to exit, most likely a reference to the celebratory games of Aeneas (see, indicatively, Kraft, 1985; Heller, 1946: 129-130; Mielczarek, 2013: 133).

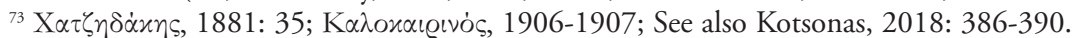

${ }^{74}$ Tyree et al., 2011; Faure, 1987; Faure, 1964: 162-173; Faure, 1963.

${ }^{75}$ Aspesi, 2016.

${ }^{76}$ Claudius Claudianus, De Sexto Consulatu Honorii 632-635.

${ }^{77}$ Ioannis Malalas, Chronography 4.107-108.

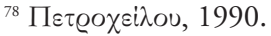


Labyrinth of Crete. This is a view that has been reproduced in the works of travelers and cartographers since the $15^{\text {th }}$ c. A.D. The complexity of the endless corridors and the many small and large halls of the cave, combined with the absolute darkness that reigns in its halls, the careful carving on the walls of the cave which continues for several kilometers, make it not just a natural site but also a monumental human work of unknown era and function. ${ }^{79}$ Equally unproven is the view that has been expressed according to which the underground structure is a stone quarry or mine, possibly of the Roman era. ${ }^{80}$ The absence, however, of any archaeological evidence, as well as the absence of Roman mines of similar type and extend, makes the characterization of the Gortynian "Labyrinth» as an ancient mine questionable.

Thus, the views regarding the location of the labyrinth have been divided since Late Antiquity and despite the systematic and almost obsessive search for it, there are no conclusive data. None of the proposed sites so far can be proven, as there may be a plethora of indications and traditions, but on the one hand the archeological evidence is missing. As Litinas concluded through the literary tradition, the association of Labyrinth with Cretan mythology was a late, Hellenistic, adoption, ${ }^{81}$ while Kotsonas adequately demonstrated «...the exceptional capacity of the Cretan Labyrinth for metamorphosis from abstract memory (in antiquity) to physical monument (in the late Medieval period)... traced its relocation from Knossos to Gortyn and back during the Medieval to modern period, and .... argued for its development into a Cretan lieu de mémoire in the early $20^{\text {th }}$ century C.E.». ${ }^{82}$

Returning to coin iconography, the labyrinthine structure seems to appear following the earliest references of Labyrinth as a physical space in the contemporary literature, reflecting, however, the creto-centric point of the myth, silent as to the episode of the Minotaur's slaughter by Theseus. It cannot, of course, be excluded that several centuries after the destruction of the Palace of Knossos until the first written reference to the Labyrinth, the Cretans used their imagination to interpret the labyrinthine ruins of the once monumental Minoan palace of Knossos still decorated with mysterious frescoes and symbols, as well as the continuous use of various labyrinthine caves in the vicinity of Knossos for cult.

The coins' diverse iconography confirms that the engravers working for the public mint did not maintain a specific image of the Labyrinth. For Knossos of late

${ }^{79}$ Kotsonas, 2018: 380-384; Paragamian - Vasilakis, 2002; Woodwow, 1949: 324-5. For a non academic overview of the site with plenty of photographic documentation, details and much useful information, see also <http://www.labyrinthos.ch/Labyrinth-Hoehle.english.html> (last accessed

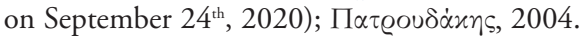

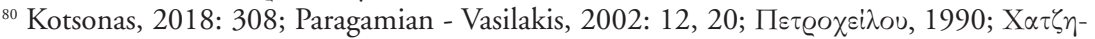
$\delta \dot{\alpha} x \eta \varsigma, 1881: 37$.

${ }^{81}$ Litinas, 2011: 467-468.

${ }^{82}$ Kotsonas, 2018: 391. 
Classical and Hellenistic times the labyrinth was not a specific building - even if it had existed in the distant past its shape had already been forgotten- but rather an abstract idea, represented freely by each artist, as long as the depiction was indicative of its complexity.

It is very likely that Knossos' authorities chose to transform an old abstract memory into a symbolic shape on the most popular object of art, the coin, as to remind citizens, Cretans and foreigners their autochthony and the connection of their city with the golden era of Minos and retained it in its various forms through centuries, as a symbol of political and economic stability ${ }^{83}$. It also may have served as a "touristic" attraction for the romantic visitors of Knossos of the Hellenistic and Roman times, who were trying to follow traces of the myth. The fact that written sources of the times are suspiciously silent is probably a sign that there was nothing conclusive about any location and shape of a specific labyrinth site on Crete. Therefore, it probably doesn't make sense to try to attribute to the monetary iconography of Knossos of the $5^{\text {th }}$ and $4^{\text {th }}$ centuries BC a role other than that of political propaganda exploiting the mythical past.

\section{THE MYSTERIOUS ANIMAL-NURSED CHILD OF KYDONIA}

An early $2^{\text {nd }} \mathrm{c}$. BC issue of silver staters and drachms of Kydonia, ${ }^{84}$ depicts a female dog breastfeeding an infant, leaning her head towards it. The inscription $\mathrm{K} Y \Delta \Omega \mathrm{N}$ is engraved in the exergue (fig. 28a-c). There has been a long discussion for more than a century regarding the scene, based on the identity of the infant, which has been identified with Kydon, the famous founder of Kydonia, Miletos, brother of Kydon and founder of the Ionian Miletus or Zeus Cretagenes.

Miletos, son of Akakallis and Apollo, has been suggested ${ }^{85}$ in the context of the myth according to which he was exposed after birth and raised by a she-wolf:

.... In Crete Apollo and Acacallis, daughter of Minos, had a child called Miletus. Fearing Minos, Acacallis exposed him in a wood. By the will of Apollo wolves would turn up to guard him and give milk in turn... ${ }^{86}$

The suggested identification, however, should be dismissed since Miletos -except for his blood ties with Kydon- had nothing to do with the city of Kydonia

${ }^{83}$ See also Mielczarek, 2013: 133.

${ }^{84}$ On the coinage of Kydonia see Stefanakis, 1997 (corpus). See also, $\Sigma \tau \varepsilon \varphi \alpha \nu \alpha \dot{\alpha} \varsigma, 2019 \alpha$ : 45-47; Le Rider, 1966: 194; Svoronos, 1890: 96-119.

${ }^{85}$ See, for example, Gardner, 1883: 167; Fiorelli, 1870: 157, no 7622; Dapper, 1836: 307-8. On Miletos see LIMC VI, 568.

${ }^{86}$ Antoninus Liberalis, Metamorphoses, 30.1. 
and the animal on the coin is clearly a female dog, most likely of the local breed of Cynosouris $^{87}$ and not a she-wolf. It may be that Antoninus Liberalis was inspired from the myth of the raising of the twins by Lupa Romana of the roman tradition. ${ }^{88}$

An identification with Kydon, again a son of Akakallis and Apollo, or Hermes ${ }^{89}$ was also suggested by many scholars on account of the Pausanias's report on the foundation of Kydonia:

...It is also said that all the surviving sons of Tegeates, namely, Cydon, Archedius and Gortys, migrated of their own free will to Crete, and that after them were named the cities Cydonia, Gortyna and Catreus. The Cretans dissent from the account of the Tegeans, saying that Cydon was a son of Hermes and of Acacallis, daughter of Minos, that Catreus was a son of Minos, and Gortys a son of Rhadamanthys ... ${ }^{90}$

Two arguments have been used to support the identification of the infant with Kydon: first, the inscription KY $\Delta \Omega \mathrm{N}$ below the scene, and second, the hypothesis that he could have a story similar to that of his brother, Miletos, since stories of infants raised by animals were quite common in Greek -and Cretan- mythology ${ }^{91}$.

Svoronos suggested that the infant was Zeus Cretagenes, based on fragmentary reports about the relationship between Zeus and dogs from ancient sources and indirect coin evidence, ${ }^{92}$ such as: the lightning that occurred on an issue of drachms and which could be an indirect reference to the identity of the represented infant; the appearance of Zeus Cretagenes on the pseudo-Athenian tetradrachms from Kydonia, replacing, in later editions, the former type of the infant ${ }^{93}$ (fig. 29); the representation of Diktynna, protector deity of the Kydonians as a divine nurse accompanied by Kouretes (fig. 30) on a silver coin of Trajan (AD 115-117), ${ }^{94}$ possibly issued by the Diktynnaion Temple, at the nearby peninsula of Spatha; ${ }^{95}$ the much later depiction of Zeus Cretagenes as an infant sitting on a sphere and accompanied by one of his dogs, on the coins of the Cretan Koinon of Roman Imperial times (fig. 31). All these were treated by Svoronos as indications that Zeus was raised by a dog

${ }^{87}$ Stefanakis, 2000a: 81-82; Stefanakis, 1997: 190.

${ }^{88} \sum \tau \varepsilon \varphi \alpha \nu \dot{\alpha} \varkappa \eta \varsigma, 2014: 614$.

${ }^{89}$ Stephanus Byz. Ethnica, entry Cydon.

${ }^{90}$ Pausanias, Description of Greece, Arcadia, 8.53.4.

${ }^{91} \sum \tau \varepsilon \varphi \alpha \nu \dot{\alpha} x \eta \varsigma$, 2014: 605-606; Stefanakis, 2000a: 83; Stefanakis, 1997: 189-190.

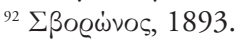

${ }^{93}$ Stefanakis, 1997: 253; Le Rider, 1968: 316-317, pl. II, 1-4.

${ }^{94}$ Verbruggen, 1981: 45; Kirsten, 1980: 264; Hatzisteliou-Price, 1978: 89, 191; 46; Svoronos, 1890: $\pi$ iv. XXXIII, 23-24.

${ }^{95}$ On the temple of Diktynna see Buxton, 1995: 108-135; Gondicas, 1988: 287-296; Kirsten, 1980; Welter - Jantzen, 1951; IC II, xi, 128-140. 
in western Crete, ${ }^{96}$ perhaps according to a lost legend of Kydonia, part of a series of myths that wanted Zeus to have being bred by various animals in Crete. ${ }^{97}$

The argument of Svoronos is quite complicated and perhaps somewhat stressed in order to provide a solution to the infant's identity. In the absence of tangible evidence, the infant's identification with Zeus should remain a possibility and it is not unlikely that there was indeed a lost myth about the first years of his life connecting him with a dog, possibly on Mount Tityros, in the Spatha peninsula. ${ }^{98}$ Equally possible, however, is the identification of the figure with Kydon. Neither of the two proposed identities can be proved because there are no ancient sources referring to a dog nursing story in the area of Kydonia (or western Crete in general) for either Zeus or Kydon. However, the identification of the infant with Kydon is currently preferred, mainly because of the inscription that accompanies the figure. Moreover, since animal raised heroes became fashionable in the Hellenistic years, a possible political decision by the authorities of Kydonia to adjust accordingly the iconography on their coins should not be ruled out.

Regardless of whether this particular scene depicts the animal nursing infancy of Zeus, or refers to the local hero Kydon, it is most likely that it was influenced by the Roman tradition of animal breeding of the founders of Rome, Romulus and Remus and their depiction on the Roman-campaign coins of the $3^{\text {rd }}$ century BC. It should rather be taken as part of the good political relations of Kydonia with Rome at the beginning of the $2 \mathrm{nd} \mathrm{c}$. BC, let alone as either a proclamation of the autochthony of the Kydonians (Kydon the founder) or a claim of the upraising of Zeus in their territory, re-enforcing thus the already «hegemonic» profile of the city over west Crete. ${ }^{99}$

The representation of the dog-nursed infant survived in the Roman Imperial times, on the bronze issues of the Kydonian mint, under the reign of Augustus (27 BC$A D$ 14.) (fig. 32), Tiberius (AD 14-57) (fig. 33), Nero (AD 54-68) (fig. 34) and Trajan (AD 98-117) (fig. 35), ${ }^{100}$ displaying thus its strong local tradition in west Crete.

\section{IMAGE AND MYTH ON ANCIENT CRETAN COINS AND LOCAL IDENTITIES}

It is a fact that the Cretan mints depict a plethora of mythical figures and episodes on their coins, often difficult to identify or interpret due to either lack of clues

${ }^{96}$ Svoronos' interpretation was accepted by many scholars such as Verbruggen, 1981: 43-44; Hadzisteliou-Price, 1978: 88-9; Nilsson, 1967: 320-321; Willetts, 1962: 276; Faure, 1960: 210, n. 2; Jannoulides, 1956: 80. For the problem of interpretation see Stefanakis, 2000a; Stefanakis, 1997: 189-191.

${ }^{97}$ On the myths regarding the birth of Zeus on Crete and the different nurses, see $\sum \tau \varepsilon \varphi \alpha-$ v่ंxทs, 2014: 606-614.

${ }^{98} \sum \tau \varepsilon \varphi \alpha \nu \dot{\alpha} \gamma \eta \varsigma, 2014: 613$.

${ }_{99}$ On the hegemonic aspirations of Kydonia over west Crete in the early $2^{\text {nd }} \mathrm{c} . \mathrm{BC}$, see $\sum \tau \varepsilon \varphi \alpha-$

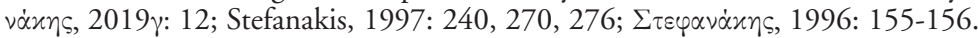

${ }^{100} \sum \tau \varepsilon \varphi \alpha v \dot{\alpha} \gamma \eta \varsigma, 2014: 614$ and n. 64. 
that would lead to an interpretation or to the fact that could be identifiable with more than one existing myth. Thus, the identification of imagery on Cretan coins is not always self evident.

Besides the cases discussed above the problem of identifying figures also applies to many other narrative scenes on Cretan coins. Ptolioikos of Aptera, ${ }^{101}$ Velchanos of Phaistos, ${ }^{102}$ or the infant who is breastfed by a cow on the coins of Praisos ${ }^{103}$ are a few more indicative examples.

The three cases presented in this paper, namely the Nymph on the Tree (Europa), the Labyrinth and the Bitch-nursed Infant (Kydon or Zeus) have produced a lot of discussion, and yet, in the last case things are not satisfactorily settled. Europa featured on the coinage of Gortyn for many centuries as a strong symbol of past legacy and autochthony. The possibility of a carefully designed iconographic program, could only be the result of a political decision of the Gortynian authorities, as to proclaim primacy over the island through their strong ties to the mother of all Cretans. The labyrinthine motives and structures on the Knossian coins rather refer to the transformation of an ancient abstract memory into a symbolic shape as to stress autochthony and the connection of their city with the glorious past of Crete and, possibly, to excite the imagination of the romantic visitor. The Bitch-nursed Infant of Kydonia, regardless of whether it refers to the infancy of Zeus, or of the local hero Kydon, besides being a proclamation of autochthony and primacy over the upraising of Zeus, it was most likely a political decision to proclaim good political relations with Rome. The strong meaning these iconographic types conveyed resulted in their preservation (with variations and alterations) on the coins for centuries, as symbols of political and economic stability.

The representation of legendary mythical heroes or creatures on Cretan coins was linking the issuing state with a certain heritage, offering a sense of belonging, continuation and pride to the citizens. Cities, through coin imagery and by carefully selecting the represented mythical figures, were shielding their identity by differentiating it from other groups, with different mythical narratives in their culture, thus fortifying bonds within the group. Finally, coin iconography could also have served to accentuate political bonds between cities.

\section{BIBLIOGRAPHY}

ACKERMANN, D. (2005): «La représentation du labyrinthe sur les monnaies de Cnossos: origine, evolution et signification", Bulletin de l'Association suisse d'Archéologie classique 2005: 33-6.

\footnotetext{
${ }^{101}$ Svoronos, 1890: pl. I, 7-10.

${ }^{102}$ Carbone, 2014-2015: 33-40 and series 41-43; Svoronos, 1890: pl. xXIII, 24-26.

${ }^{103} \sum \tau \varepsilon \varphi \alpha \nu \dot{\alpha} x \eta \varsigma$, 2014: 609-610; Svoronos, 1890: pl. XXVII, 2.
} 
AlfÖLDI, A. (1956): «The Main Aspects of Political Propaganda on the Coinage of the Roman Republic», in C. H. V. SutherLAND - R. A. G. CARSON (eds.), Essays in Roman coinage: presented to Harold Mattingly, Oxford University Press.

ANDREWS, P. B. S. (1969): «The myth of Europa and Minos», Greece and Rome 16: 60-66.

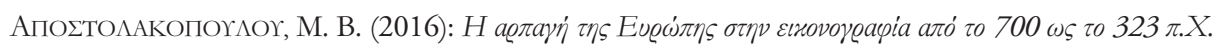

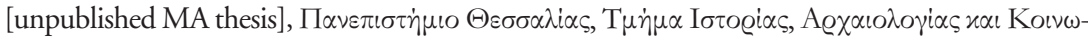

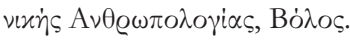

ASPESI, F. (2016): «Il labirinto all'Amnisos», AISN 5: 13-38.

BMC Attica = HEAD, B. (1888): Catalogue of Greek Coins in the British Museum, Attica-Megaris - Aegina, London.

BMC Crete = Wroth, W. (1886): A Catalog of the Greek Coins in the British Museum, Greek Coins of Crete and the Aegean Islands, London.

Boregeaud, P. (1974): «The open entrance to the closed palace of the king. The Greek Labyrinth in its context", History of Religions XIV: 1-27.

BÜHLER, W. (1968): Europa. Ein Überblick über die Zeugnisse des Mythos in der antiken Literatur und Kunst, München.

BuxTON, B. A. (1995): Diktynna. Myth and Cult [unpublished MA Thesis], Victoria University of Wellington.

CARBONE, F. (2014-2015): Usi monetari a Gortina e Festòs: cronologie e aspetti produttivi [unpublished Ph.D. thesis], Universitá degli Studi di Salerno.

CARrIER, C. (2013): "Cas d'imitation monétaire à Cnossos: la série à la tête d'Héra et la cité d'Argos», Bulletin de la Société Française de Numismatique 8: 231-241.

Castelden, R. (1990): The Knossos Labyrinth: a New View of the Palace of Minos at Knossos, Routledge.

CLAYTON, P. C. (1988): «The coinage of Knossos, the Minotaur legend and the archaeological evidence», Seaby Coin and Medal Bulletin 830 [May]: 106-7; 831 [June]: 131-3; 832 [July/August]: 163-6.

Coldstream, J. N. (1973): Knossos: the sanctuary of Demeter, Thames \& Hudson for the British School of Archaeology at Athens, London.

Crawford, M. H. (1974): Roman Republic Coinage, Cambridge.

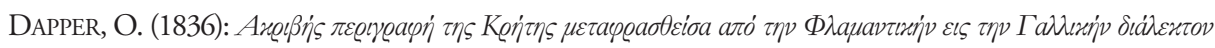

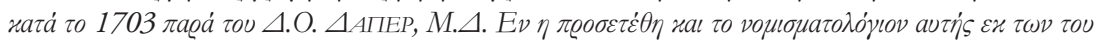

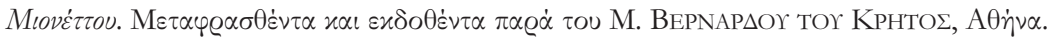

Detienne, M. (1983): «La grue et le labyrinthe», Mélanges de l'Ecole française de Rome Antiquité 95.2: 541-553.

Devoto, C. (2019): «Some Remarks on the Chronology of the First Coins of Knossos, Crete», Adalya 22: 145-165.

DooB, P. R. (1990): The Idea of the Labyrinth from Classical Antiquity through the Middle Ages, Ithaca.

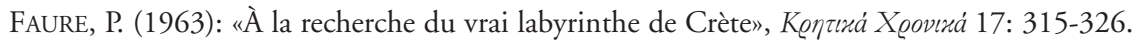

Faure, P. (1964): Fonctions des Cavernes Crétoises, École française d'Athènes, Travaux et mémoires 14, E. de Boccard, Paris.

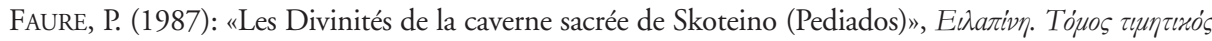

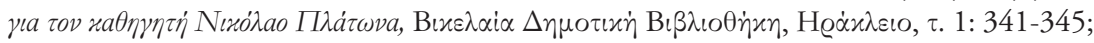

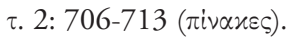

Fiorelli, G. (1870): Catalogo del Museo Nazionale di Napoli. Medagliere I, Monete Greche, Napoli. 
FORRER, L. (1900): «Le labyrinthe de Knossos et ses representations sur les monnaies», SNR 10: 193-211. GallavotTi, C. (1957): «Labyrinthos», La Parola del Passato. Rivista di Studi Antichi 12: 161-176. GARDNER, P. (1883): The types of Greek Coins, Cambridge.

GODART, L. (1975): «Il labirinto e la Potnia nei testi mivenei», Rendiconti dell' Accademia di Archaeologia, Lettere e Belle Arti di Napoli 50: 141-152.

GONDICAS, D. (1988): Recherches sur la Crète Occidentale, Amsterdam.

GuarduCCI, M. (1949): «A presunta leggenda Tisyroi nelle monete di Gortyna», Arch.Classica 1: 172-176.

HADZISTELIOU-PRICE, Th. (1978): Kourotrophos, cults and representations of the Greek nursing deities, Leiden.

HeLler, J. (1946): «Labyrinth or Troy Town?», The Classical Journal 42.3: 123-139.

IC II = GuarduCCI, M. (1939): Inscriptiones Creticae, II. Tituli Cretae Occidentalis, Roma.

JACKSON, A. E. (1971a): «The bronze coinage of Gortyna», NC 7/11: 37-51.

JACKSON, A. E. (1971b): «The chronology of the bronze coins of Knossos», BSA 66: 285-295.

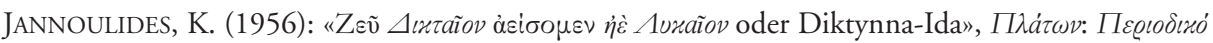

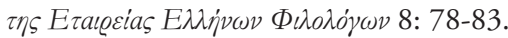

KäHLER, H. (1949): Das Griechische Metopenbild, München.

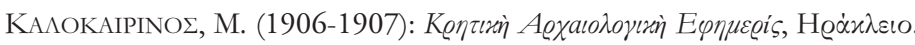

KERÉNYI, K. (1950): Labyrinth-Studien. Labyrinthos as Linienreflex einer mythologischen Idee, Zürich.

KERN, H. (1982): Labyrinth. Erscheinungsformen und Deutungen. 5000 Jahre Gegenwart eines Urbilds, München.

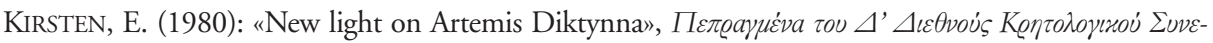

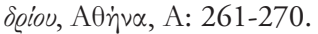

Kotsonas, A. (2018): «A Cultural History of the Cretan Labyrinth: Monument and Memory from Prehistory to the Present», American Journal of Archaeology 122.3: 367-396.

KRAFT, J. (1985): «The Cretan Labyrinth and the walls of Troy, an analysis of Roman Labyrinth design», Opusculla Romana 15: 79-86.

Kroll, J. H. - Walker, A. S. (1993): The Greek Coins (Athenian Agora, Vol. 26), American School of Classical Studies at Athens.

LE Rider, G. (1966): Monnaies Crétoises du ve au Ir siècle av. J-C, Ecole Française d' Athènes, Études Crétoises 15, Paris.

LE RIDER, G. (1968): «Une groupe de monnaies crétoises à type Athéniens», Humanism actif. Mélanges d'art et de littérature offerts à Julien Cain, Paris, 313-35.

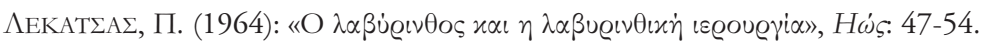

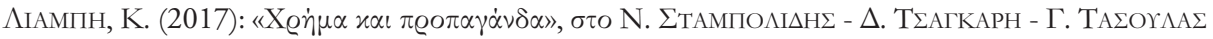

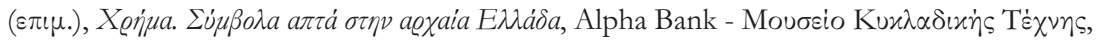
A $\theta \dot{\eta} v \alpha, 223-262$.

LIMC = Lexicon Iconographicum Mythologiae Classicae (1981-1997): Zürich and München.

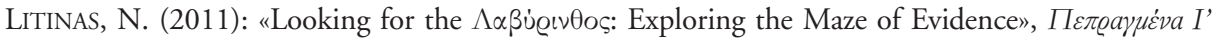

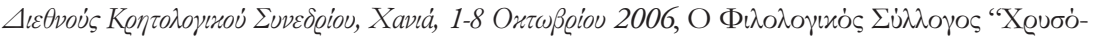

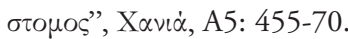

Marconi, C. (2007): Temple Decoration and Cultural Identity in the Archaic Greek World, The Metopes of Selinus, Cambridge University Press, Cambridge. 
McWilliam, J. - Puttock, S. - Stevenson, T. (2011): The Statue of Zeus at Olympia: New Approaches, Cambridge Scholars Publishing, Newcastle upon Tyne.

MielczareK, M. (2013): «More on the labyrinth on the coins of Knossos», Studies in Ancient Art and Civilization 17: 127-138.

NASTER, P. (1947): «La légende $\Sigma$ IBPYTISI sur des monnaies de Sybrita», Revue belge de Numismatique XCIII: $35-40$.

NiLssOn, M. P. (1967): Geschichte der Griechischen Religion I, Handbuch der Altertumswissenschaft 5.2.1, München.

Østby, E. (1987): «Riflessioni sulle metope di Selinunte», Parola del Passato XLII: 123-153.

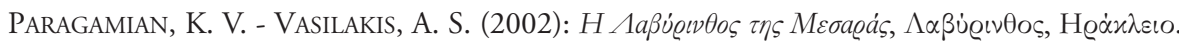

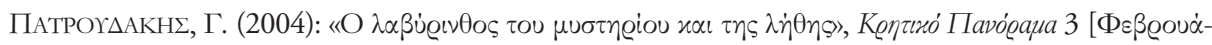

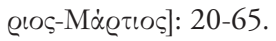

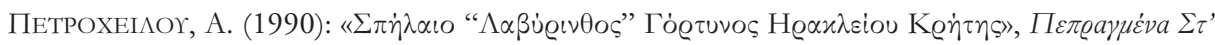

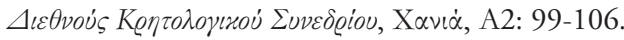

PRENT, M. (2005): Cretan sanctuaries and cults: continuity and change from Late Minoan IIIC to the Archaic period. Religions in the Graeco-Roman world, Brill, v. 154, Leiden.

PRICE, M. J. (1991): The Coinage in the Name of Alexander the Great and Philip Arrhidaeus, vol 1, Zürich-London.

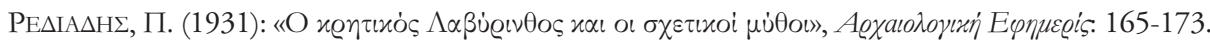

ReEves, B. T. (2003): The Rape of Europa in Ancient Literature [unpublished Ph.D. thesis], McMaster University.

Richter, G. M. A. (1966): «The Pheidian Zeus at Olympia», Hesperia 35.2: 166-170.

Rieche, A. (1978): «Zur Leda des Timotheos», Nachtrag zu Antike Plastik 17: 21 - 55.

Rieche, A. (2010): «Verweigerte Rezeption. Sur Wirkungsgeschichte der Leda des Timotheos», in Das Originale der Kopie: Kopien als Produkte und Medien der Transformation von Antike, Berlin New York, 117-136.

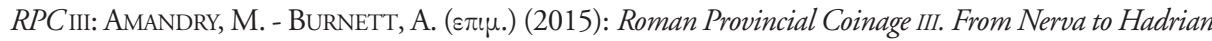
(AD 96-138), Bibliotheque nationale de France - British Museum Press, Paris - London.

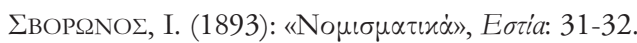

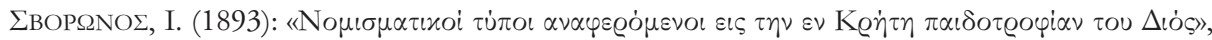

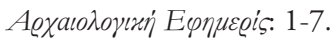

Shavernoch, H. (1975): «Ariadne, der Minotauros und das Labyrinth», Antike Welt 6.1: 14-27.

Silvestrelli, F. (1998): «Il ratto di Europa tra settimo e quinto secolo a.C.: dall'iconografia all'iconologia», Ostraka V: 159-198.

Sippel, D. V. (1986): «The supposed site of the Cretan Labyrinth», Ancient World 14: 67-79.

SNG Copenhagen = Sylloge Nummorum Graecorum [Denmark]. The Royal Collection of Coins and Medals. Danish National Museum (1944): Part 14: Attica - Aegina, Copenhagen.

SNG Lockett = Sylloge Nummorum Graecorum [Great Britain]. The Lockett Collection (1942): vol. 4: Peloponnese - Aeolis, London.

SNG von Aulock $=$ Sylloge Nummorum Graecorum [Deutschland]. Sammlung v. Aulock (1957): vol. 1: Pontus, Paphlagonia, Bithynia, Mysia, Troas, Aiolis, Lesbos, Ionia, Berlin. 


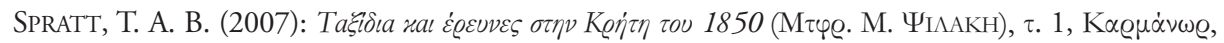

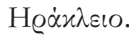

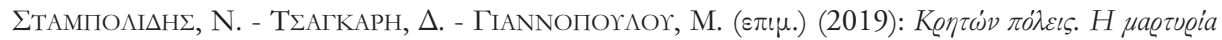

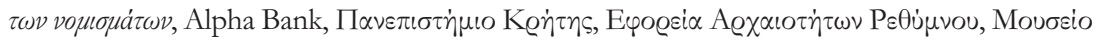

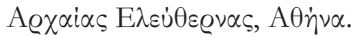

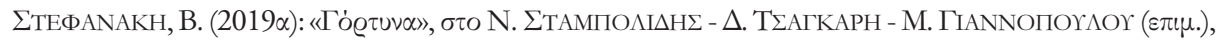

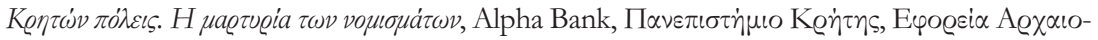

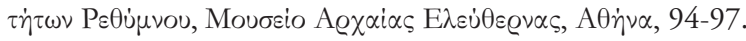

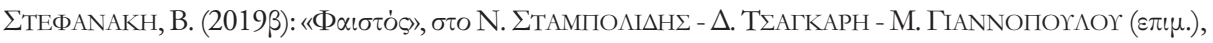

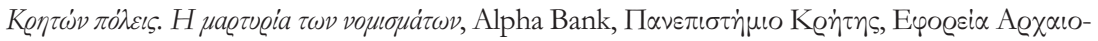

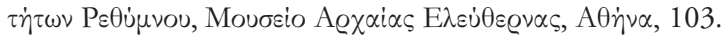

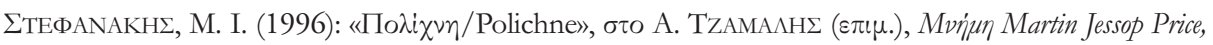

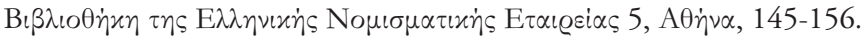

इTEФANAKH 9: 43-57.

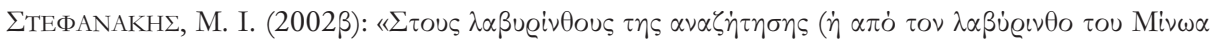

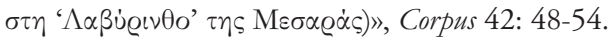

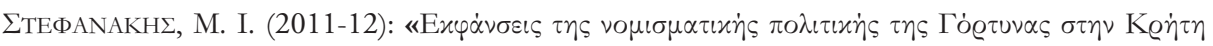

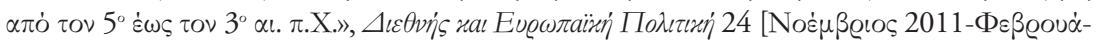
Qlos 2012]: 71-86.

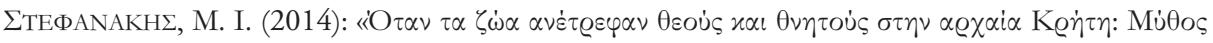

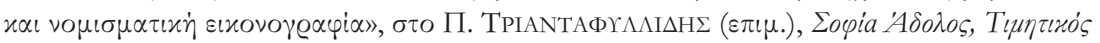

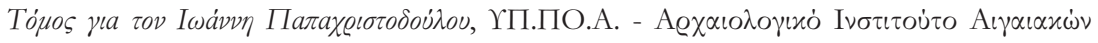
$\sum \pi \circ u \delta \dot{\omega} v, A \theta \dot{\eta} v \alpha, 605-624$.

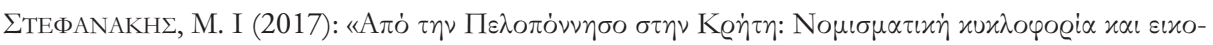

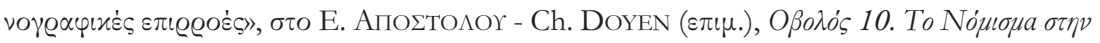

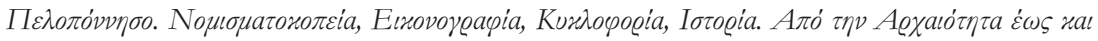

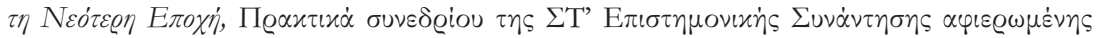

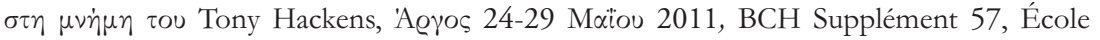

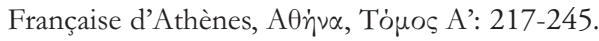

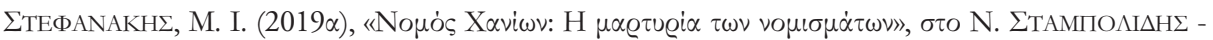

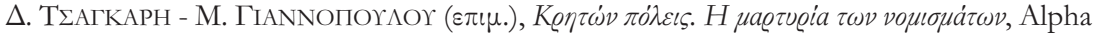

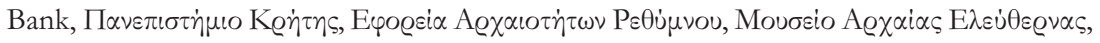
A $\theta \dot{n} v \alpha, 44-55$.

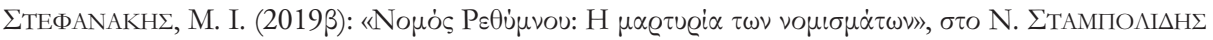

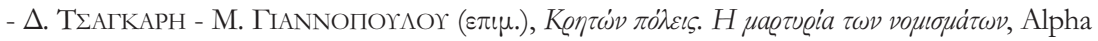

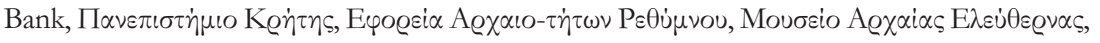
A $\theta \dot{\eta} v \alpha, 66-77$.

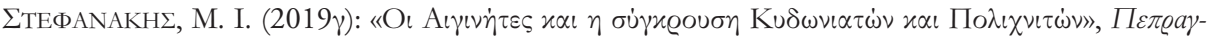

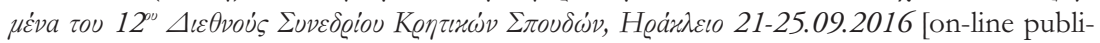
cation: https://12iccs.proceedings.gr/el/proceedings/category/38/32/653].

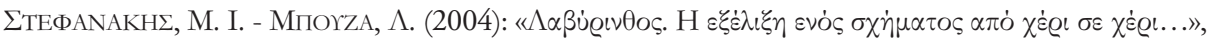

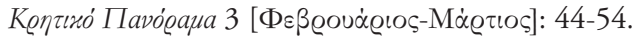

STEFANAKIS, M. I. (1997): Studies in the Coinages of Western Crete with particular reference to Kydonia [unpublished Ph.D. thesis], London. 
STEFANAKIS, M. I. (2000a): «Kydon the oikist or Zeus Kretagenes Kynotraphes? The problem of interpreting Cretan coin-types», Euגısiv 1: 63-73.

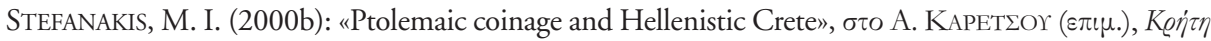

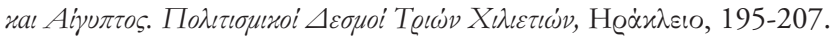

Svoronos, J. (1890): Numismatique de la Crète Ancienne, Mâcon.

SVORONOS, J. (1894a): «Britomartis, the so-called Europa on the plane tree of Gortyna; a monograph on certain Cretan Coins", American Journal of Numismatics 29.1: 1-9 [= first part of SvORONOS, J. (1894): «Britomartis. La soi-disant Europa sur le platane de Gortyne», Revue Belge de Numismatique et Sigillographie 50: 113-147].

SVORONOS, J. (1894b): «Britomartis, the so-called Europa on the plane tree of Gortyna; a monograph on certain Cretan Coins", American Journal of Numismatics, 29.2: 33-41 [= second part of Svoronos, J. (1894): «Britomartis. La soi-disant Europa sur le platane de Gortyne», Revue Belge de Numismatique et Sigillographie 50: 113-147].

Svoronos, J. N. (1975): Les monnaies d'Athnes, completed by B. PICK, Munich [1923-1926 = Reprinted with translated text as Corpus of the Ancient Coins of Athens, Chicago].

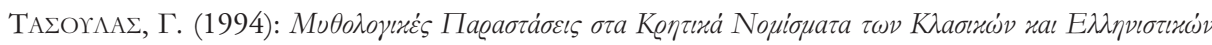

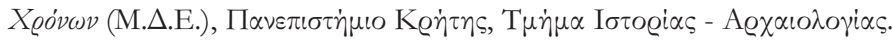

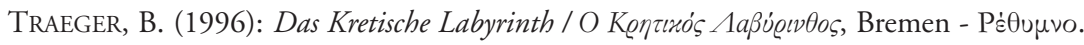

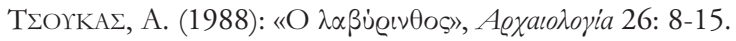

Tyree, L. - Sphakianakis, D. - Stamos, A. - Frey, J. - Belidis, M. - KamnaKis, S. (2011): «Speleography of Skoteino: Natural relief formations of the cave's interior, with special reference to Late

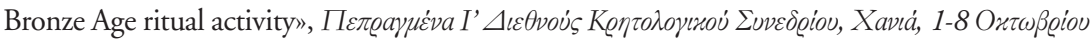

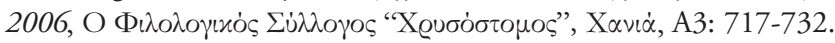

Verbruggen, H. (1981): Le Zeus Cretois, Paris.

VIN, J. P. A. VAN DER (1974-1975): «Het labyrinth van Knossos», Geuzenpenning Munt-en Penningkundig Nieuws 25.1 [Dec. 1974-Jan. 1975]: 6-10.

Voegtli, H. (1977): Bilder der Heldenepen in der kaiserzeitlichen griechischen Münzprägung, Basel.

Waldhauer, O. (1915): Pythagoras of Rhegium [in Russian], Petrograd.

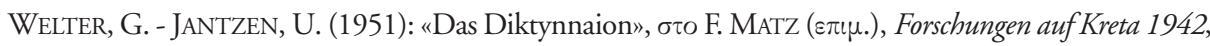
Berlin, 106-117.

WilletTs, R. F. (1962): Cretan Cults and Festivals, London.

Woodwow, A. M. (1949): «The Gortyn «Labyrinth» and its visitors in the fifteenth century», Annual of the British School at Athens 44: 324-5.

Woytek, B. E. (2012): The Denarius Coinage of the Roman Republic, Oxford Handbooks Online [DOI: http://dx.doi.org/10.1093/oxfordhb/9780195305746.013.0018].

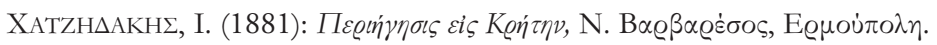

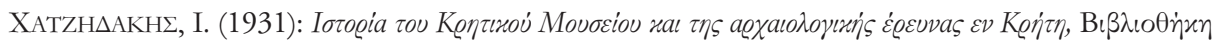

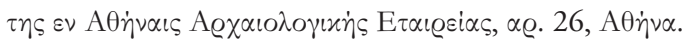

ZAHN, E. (1983): Europa und der Stier, Würzburg. 


\section{ANCIENT SOURCES}

AlEXANDER POLYHISTOR (1876): Fragmenta = Cory's Ancient Fragments of the Phoenician, Carthaginian, Babylonian, Egyptian and other authors; A New and Enlarged Edition, with an English translation by E. Richmond Hodges, Reeves \& Turner, London.

ANTONINUS Liberalis (2015): Metamorphoses = The Metamorphoses of Antoninus Liberalis; A translation with a Commentary, with an English Translation by F. CELORIA, Routledge, London.

APOLlODORUS (1921): Library Epitome= Apollodorus, The Library; with an English translation by Sir James George Frazer, F.B.A., F.R.S. in 2 Volumes, Harvard University Press - William Heinemann Ltd., Cambridge, MA - London.

Apollonius Rhodius (1912): Argonautica = Apollonius Rhodius, Argonautica ;ith introduction and commentary by G. W. MoONEY, Longmans, Green \& co., London.

Callimachus (1921): Hymns and Epigrams, Hymn to Artemis / Hymn to Delos = Callimachus, Hymns and Epigrams. Lycophron: Alexandra. Aratus: Phaenomena; with an English translation by A. W. MAIR - G. R. MAIR, Loeb Classical Library, volume 129, William Heinemann Ltd., London.

Claudian (1996): Panegyricus de Sexto Consulatu Honorii Augusti = Claudian, Panegyricus de Sexto Consulatu Honorii Augusti; by M. DeWAR, Oxford University Press, London.

Herodotus(1920): Historiae = Herodotus; with an English translation by A. D. Godley, Harvard University Press, Cambridge.

HOMER (1919): Odyssey = Homer. The Odyssey; with an English translation by A. T. MurraY, Ph.D. in two volumes, Harvard University Press - William Heinemann, Ltd. Cambridge, MA - London.

IOANNIS MaLALAS (1986): Chronography = The Chronicle of John Malalas; A Translation, by E. JefFreYs, M. JefFreys, R. SCOTt et al., Byzantina Australiensia 4, Australian Association for Byzantine Studies, Melbourne.

ISOCRATES (1980): Encomium of Helen = Isocrates; with an English Translation in three volumes, by George Norlin, Ph.D., LL.D. Harvard University Press - William Heinemann Ltd., Cambridge, MA - London.

Moschus (1912): Europa = The Greek Bucolic Poets, with an English Translation by J. M. EDMONDS, Loeb Classical Library Volume 28, Harvard University Press, Cambridge, MA.

Ovid (1922): Metamorphoses = Ovid's Metamorphoses, Brookes More, Cornhill Publishing Co., Boston.

PAUSANIAS (1918): Description of Greece, Elis = Pausanias Description of Greece with an English translation by W. H. S. Jones, Litt.D. - H. A. Ormerod, M.A., in 4 Volumes, Harvard University Press - William Heinemann Ltd., Cambridge, MA - London.

Philostratus (1912): The life of Apollonius of Tyana = Philostratus. The life of Apollonius of Tyana, the Epistles of Apollonius and the Treatise of Eusebius, with an English translation by F. C. CONYBEARE, Harvard University Press, Cambridge, Mass.

Plato (1925): Minos = Plato in Twelve Volumes, with an English translation by W. R. M. Lamb, Harvard University Press - William Heinemann Ltd., Cambridge, MA - London.

Plutarch (1914): Theseus = Plutarch. Lives. Theseus and Romulus. Lycurgus and Numa. Solon and Publicola, with an English translation by Bernadotte PERRIN, Harvard University Press William Heinemann Ltd., Cambridge, MA - London.

STEPHANUS BYZANTINUS (1873): Ethnica $=$ A Dictionary of Greek and Roman biography and mytholo$g y$, William SMith, Spottiswoode and Co., London.

THEOCRITUS (1912): Bucolics = Theocritus, Idylls, with an English translation by J. M. EDMONDS. 
Theophrastus (1916): Historia Plantarum = Theophrastus. Enquiry into Plants, volume I: Books 1-5, with an English translation by Arthur F. HORT, Loeb Classical Library 70, Harvard University Press, Cambridge, MA.

VIRGIL (1900): Aeneid = Bucolics, Eneid, and Georgics of Virgil, by J. B. GreENOUGH, Ginn \& Co., Boston.

\section{FIGURES}

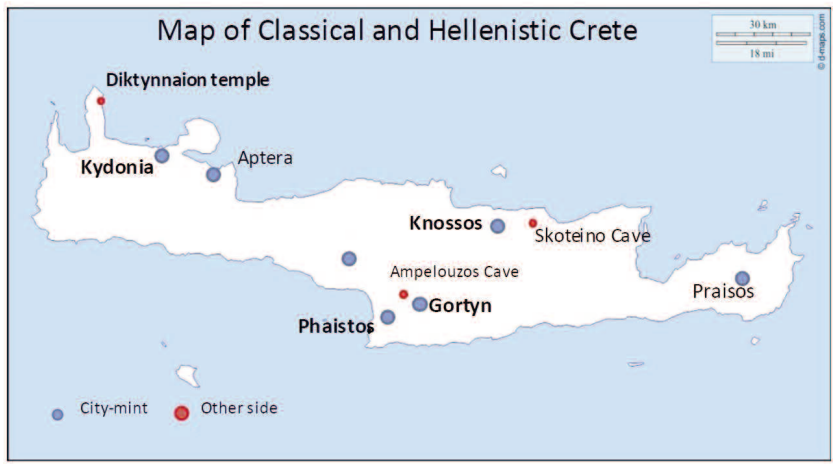

Fig. 1. Map of Classical and Hellenistic Crete.
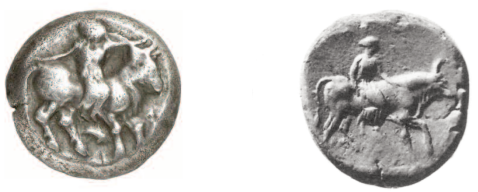

Fig. 2a-b. Gortyn, AR stater, c. 450-425 BC:
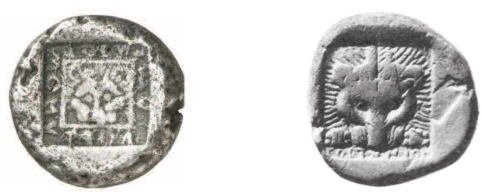

a. (11.74 gr.) Künker 136, 10.03.2008, lot 61; b. (11,87 gr.) Le Rider, 1966: pl. XI, 12 .

Fig. 3a-b. Phaestos, AR stater, c. 450-425 BC: a. (11,87 gr.) Svoronos, 1890: pl. XXII, 34;

b. (11.20 gr.) Künker 136, 10.03.2008, lot 289 .
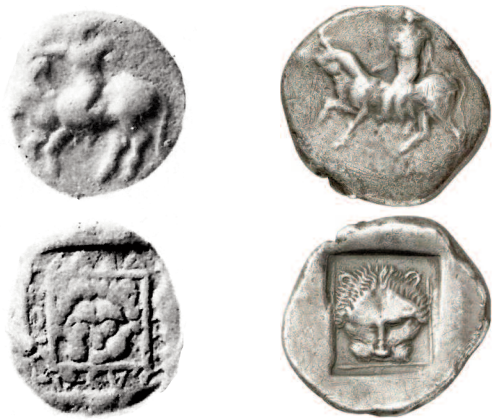

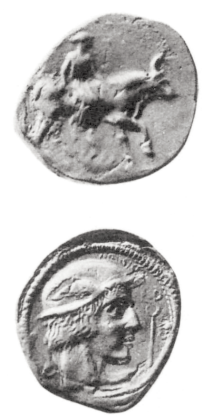

Fig. 4. Gortyn, AR stater (11,82 gr.), c. 380 BC: Le Rider, 1966: pl. XI, 10.
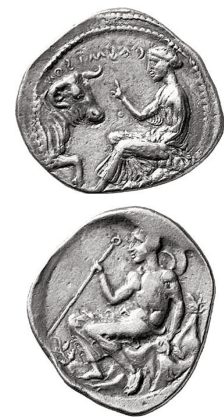

Fig. 6. Phaestos, AR stater (12.05 gr.), c. 360350 BC: Leu Numismatik AG Auction 81, 16.05.2001, lot 234.

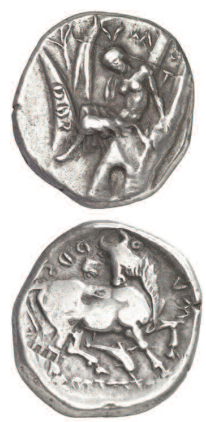

Fig. 8. Sybritos, AR stater (11,98 gr.), c. 360/50340/30 BC: LHS Numismatics 100, 23.04.2007, 281.
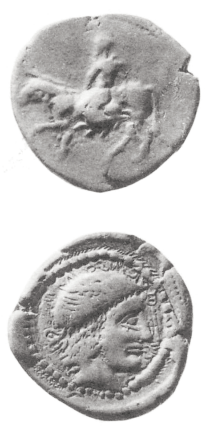

Fig. 5. Phaestos, AR stater (12,04 gr.), c. 380 BC: Le Rider, 1966: pl. xx, 23.

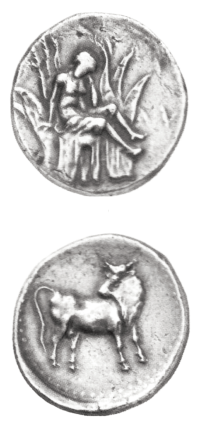

Fig. 7. Gortyn, AR stater (11.67 gr.), c. 360/50340/30 BC: Künker 136, 10.03.2008, 67.

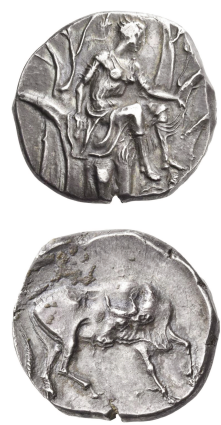

Fig. 9. Gortyn, AR stater (11.72 gr.), c. 300280/70 BC: Nomos, Auction 18, 05.05.2019 lot 130 . 


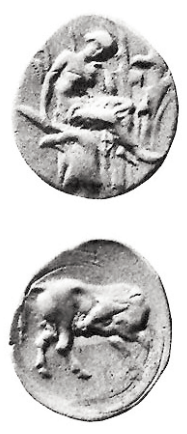

Fig. 10. Gortyn, AR stater (12,06 gr.), c. 322300 BC: Le Rider, 1966: pl. XVIII, 15.

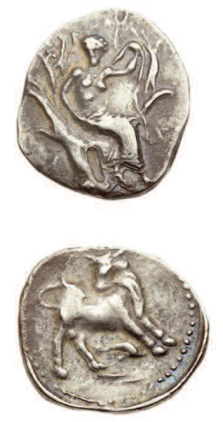

Fig. 12. Gortyn, AR stater (11.25 gr.), c. 300280/70 BC: Ira \& Larry Goldberg Coins \& Collectibles, Inc. Auction 96, 14.02.2017, lot 1674 .

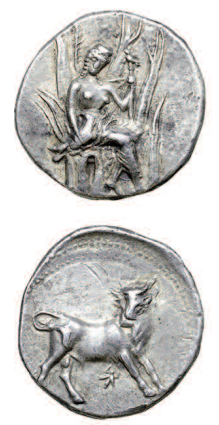

Fig. 14. Gortyn, AR stater (11.76 gr.), c. 300280/70 BC: Roma Numismatics Ltd, Auction 17, 28.03.2019, lot 431 .

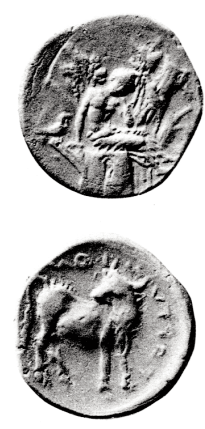

Fig. 11. Gortyn, AR stater (11,44 gr.), c. 322300 BC: Le Rider, 1966: pl. XVI, 15.

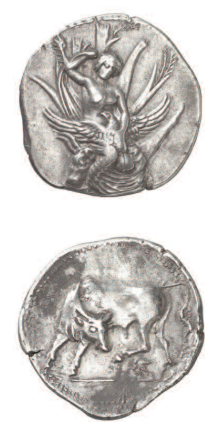

Fig. 13. Gortyn, AR stater (11.22 gr.), c. 300280/70: LHS Numismatics 100, 23.04.2007, lot 276.

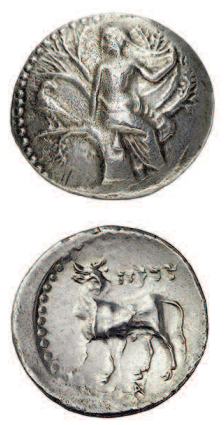

Fig. 15. Gortyn, debased AR stater (6.77 gr.), c. 260-250 BC: Gorny and Mosch Giessener Muenzhandlung, Auction 236, 07.03.2016, lot 207. 

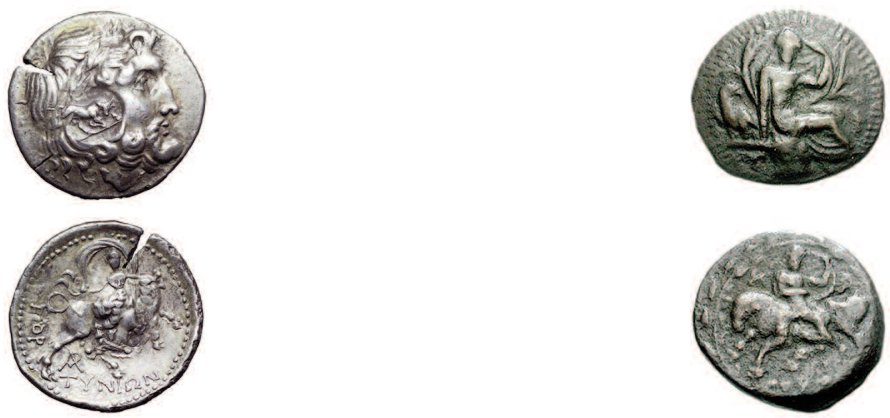

Fig. 16. Gortyn, AR Drachm (5.19 gr.), c. $250-$ 230 BC: Roma Numismatics Ltd, Auction 7 , 22.03.2014, lot 498 .
Fig. 17. BC Gortyn, AE denomination (4.99 gr., $18 \mathrm{~mm})$, c. 250-221 BC: Classical Numismatic

Group Inc., Mail Bid Sale 76, 12.09.2007, lot 614
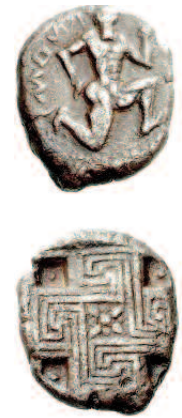
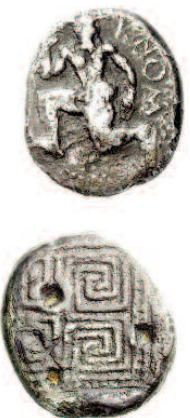
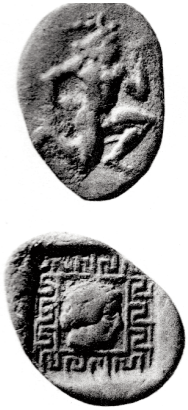

Fig. 18a-c. Knossos AR staters:

a: (11.92 gr.) ca 425-360 (?) BC Numismatica Ars Classica NAC AG, Auction 39, 16.05.2007, lot 55; b: (11,84 gr.) ca 420-380 (?) BC Numismatik Lanz München, Auction 145, 05.01.2009, lot 23; c: $(11,95$ gr.) ca 425-360 (?) BC Le Rider, pl. Xxxv, 1.
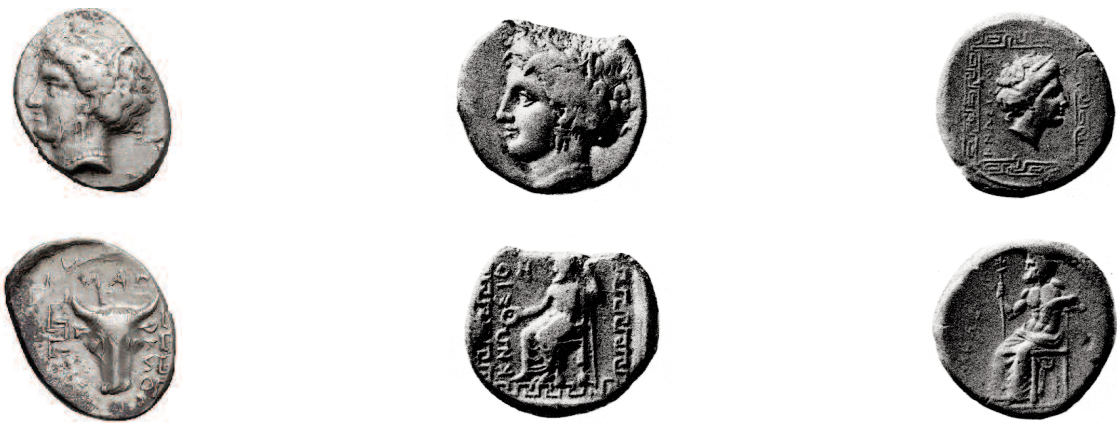

Fig. 19a-c. Knossos AR staters:

a: (11,20 gr.) ca 360/50-320 BC (?), Harlan J. Berk Ltd, Buy or Bid Sale 199, 29.09.2016, lot 106; b: (11,75 gr.) 360/50-320 BC (?), Le Rider, pl. XXV, 2; c: (11,50 gr.) 360/50-320 BC (?), Le Rider, pl. XXV, 3. 


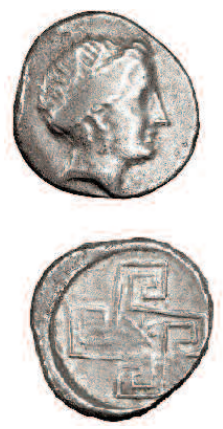

Fig. 20. Knossos AR stater (10.72g.), ca. 320 300 BC, Harlan J. Berk Ltd., Buy or Bid Sale 208, 05.09.2019, lot 226.

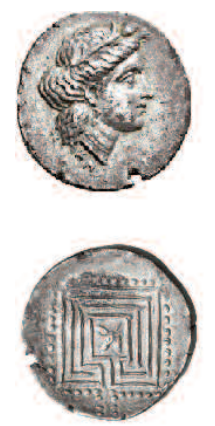

Fig. 22. Knossos AR stater (10.84 gr.), ca. 300280/70 BC. Hess Divo AG, Auction 335, 06.12.2018, lot 43 .

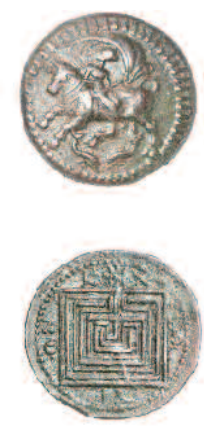

Fig. 24. Knossos and Gortyn AE denomination (4.52 gr) ca 220 (?). Fritz Rudolf Künker

GmbH \& Co. KG, Auction 124, 16.03.2007, lot 7981 .

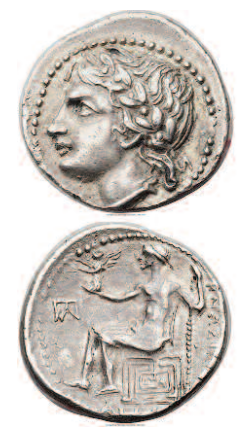

Fig. 21. Knossos AR drachm (4.88 gr.), ca 300-280/70 BC, Heritage Auctions, Inc., Auction 3056, 03.08.2017, lot 30060.

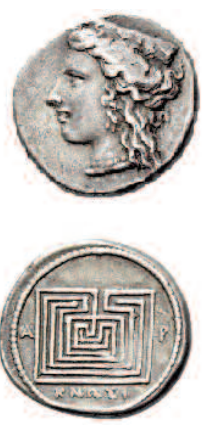

Fig. 23. Knossos AR drachm (5.41 gr.), ca 300-280/70 BC, Numismatica Ars Classica NAC AG, Auction 114, 06.05.2019, lot 212.

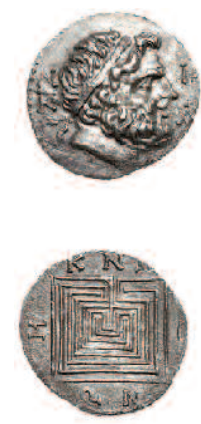

Fig. 25. Knossos AR tetradrachm (15.39 gr.), end of $2^{\text {nd }} c$. BC, Ira \& Larry Goldberg Coins \& Collectibles, Inc. Auction 96, 14.02.2017, lot 1676. 

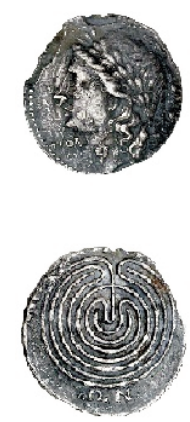

Fig. 26. Knossos AR tetradrachm (13.62 gr.), end of $2^{\text {nd }}$ c. BC, Stack's, Ancient \& World Coin Auction January 2007, 15.01.2007, lot 4098 .
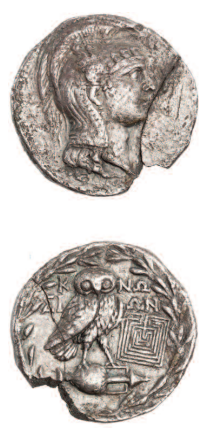

Fig. 27. Knossos AR pseudo-Athenian AR tetradrachm (14.62 gr.), ca. 87/6-67 BC. ANS 1944.100.40384 (http://numismatics.org/collection/1944.100.40384?lang=el).

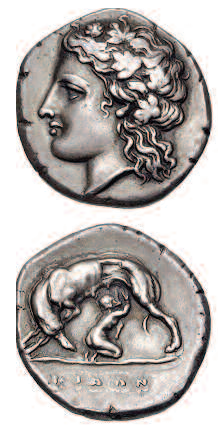

a. Electrotype «Stater» $(23.5 \mathrm{~mm}, 10.47 \mathrm{~g}, 2 \mathrm{~h})$ of BMC Crete, p. 28,7 (9,05 gr), $1^{\text {st }}$ half of $2^{\text {nd }} \mathrm{c} . \mathrm{BC}$. Classical Numismatic Group, Inc., Electronic Auction 445, 05.06.2019, lot 859 (unsigned British Museum electrotype by Robert Ready or his sons);

b. AR Drachm (5.02 gr), $1^{\text {st }}$ half of $2^{\text {nd }}$ c. BC. Fritz Rudolf Künker GmbH \& Co. KG, Auction 136, 10.03.2008, lot 231;

c. AR Drachm, (4.23 gr). $1^{\text {st }}$ half of $2^{\text {nd }}$ c. BC. Freeman $\&$ Sear, Mail Bid Sale 13, 25.08.2006, lot 11.

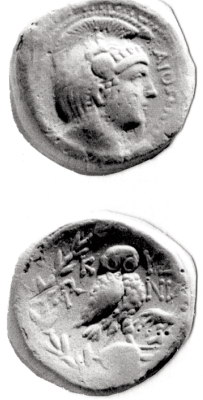

Fig. 29. Kydonia, AR pseudo-Athenian tetradrachm (15,37 gr.), ca 87/6-67 BC. Stefanakis, 1997: no 348.
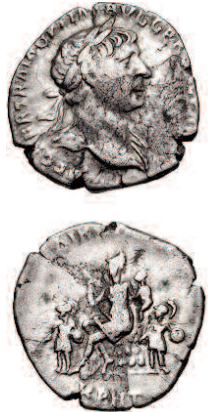

Fig. 30. Koinon of Crete, AR Drachm (17 mm, 3.06 gr, 6 h). Trajan, AD 98-117. Classical Numismatic Group, Inc. Electronic Auction 345, 25.02.2015, lot 95. 

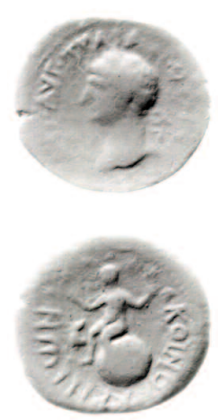

Fig. 31. Koinon of Crete, AE Denomination (5.61 gr., $25 \mathrm{~mm}$ ). Trajan. ca. AD 115(?), $R P C$ III, 35.

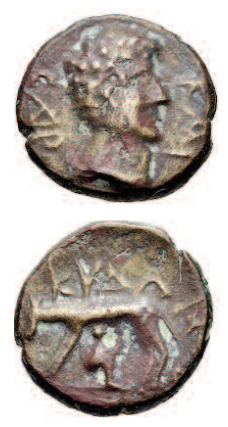

Fig. 33. Kydonia, Æ Denomination $(4.52 \mathrm{gr}$, $17 \mathrm{~mm}, 7 \mathrm{~h})$. Tiberius. AD 14-37. Classical Numismatic Group, Inc. Electronic Auction 351, 20.05.2015, lot 486 .

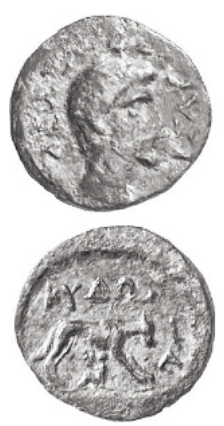

Fig. 32. Kydonia, AE Denomination (5,90 gr). Augustus, 27 BC-AD 14. Dr. Busso Peus Nachfolger, Auction 366, 29.10.2000, lot 469 .

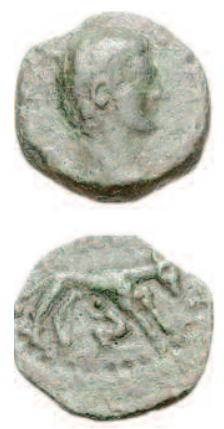

Fig. 34. Kydonia, AE Denomination (7.18 gr, $18 \mathrm{~mm}, 12 \mathrm{~h}$ ). Nero. AD 54-68. Classical Numismatic Group, Inc., Mail Bid Sale 78, 14.05.2008, lot 1258 .

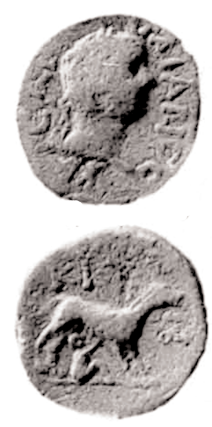

Fig. 35. Kydonia, AE Denomination (19 mm.). Traian. AD 98-117. Svoronos, 1890: pl. X, 26. 
